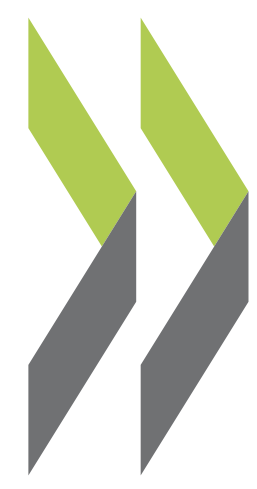

OECD Economics Department Working Papers No. 1142

\title{
Trade Patterns in the 2060 World Economy
}

\author{
Jean Château, \\ Lionel Fontagné, \\ Jean Fouré, \\ Asa Johansson, \\ Eduardo Olaberría
}


Organisation de Coopération et de Développement Économiques

Organisation for Economic Co-operation and Development

01-Dec-2014

ECONOMICS DEPARTMENT

English - Or. English

TRADE PATTERNS IN THE 2060 WORLD ECONOMY

ECONOMICS DEPARTMENT WORKING PAPERS No. 1142

By Jean Château, Lionel Fontagné, Jean Fouré, Åsa Johansson and Eduardo Olaberría

OECD Working Papers should not be reported as representing the official views of the OECD or of its member countries. The opinions expressed and arguments employed are those of the author(s).

Authorised for publication by Jean-Luc Schneider, Deputy Director, Policy Studies Branch, Economics Department.

All Economics Department Working Papers are available through OECD internet website at www.oecd.org/eco/workingpapers

JT03367521

Complete document available on OLIS in its original format

This document and any map included herein are without prejudice to the status of or sovereignty over any territory, to the delimitation of international frontiers and boundaries and to the name of any territory, city or area. 
OECD Working Papers should not be reported as representing the official views of the OECD or of its member countries. The opinions expressed and arguments employed are those of the author(s).

Working Papers describe preliminary results or research in progress by the author(s) and are published to stimulate discussion on a broad range of issues on which the OECD works.

Comments on Working Papers are welcomed, and may be sent to OECD Economics Department, 2 rue André-Pascal, 75775 Paris Cedex 16, France, or by e-mail to eco.contact@oecd.org

This document and any map included herein are without prejudice to the status of or sovereignty over any territory, to the delimitation of international frontiers and boundaries and to the name of any territory, city or area.

The statistical data for Israel are supplied by and under the responsibility of the relevant Israeli authorities. The use of such data by the OECD is without prejudice to the status of the Golan Heights, East Jerusalem and Israeli settlements in the West Bank under the terms of international law.

\section{() OECD (2014)}

You can copy, download or print OECD content for your own use, and you can include excerpts from OECD publications, databases and multimedia products in your own documents, presentations, blogs, websites and teaching materials, provided that suitable acknowledgment of OECD as source and copyright owner is given. All requests for commercial use and translation rights should be submitted to rights@oecd.org 


\section{ABSTRACT/RÉSUMÉ \\ Trade Patterns in the 2060 World Economy}

This paper presents long-term trade scenarios for the world economy up to 2060 based on a modelling approach that combines aggregate growth projections for the world with a detailed computable general equilibrium sectoral trade model. The analysis suggests that over the next 50 years, the geographical centre of trade will continue to shift from OECD to non-OECD regions reflecting faster growth in non-OECD countries. The relative importance of different regions in specific export markets is set to change markedly over the next half century with emerging economies gaining export shares in manufacturing and services. Trade liberalisation, including gradual removal of tariffs, regulatory barriers in services and agricultural support, as well as a reduction in transaction costs on goods, could increase global trade and GDP over the next 50 years. Specific scenarios of regional liberalisation among a core group of OECD countries or partial multilateral liberalisation could, respectively, raise trade by $4 \%$ and $15 \%$ and GDP by $0.6 \%$ and $2.8 \%$ by 2060 relative to the status quo. Finally, the model highlights that investment in education has an influence on trade and high-skill specialisation patterns over the coming decades. Slower educational upgrading in key emerging economies than expected in the baseline scenario could reduce world exports by $2 \%$ by 2060 . Lower up-skilling in emerging economies would also slow-down the restructuring towards higher value-added activities in these emerging economies.

JEL classification codes: E23, E27, F02, F17, F47

Keywords: General equilibrium trade model, long-term trade and specialisation patterns, trade liberalisation.

$* * * * * * * * * * * * * * * * * * * * * * * * * * * * * * * *$

\section{Tendances des échanges dans l'économie mondiale à l'horizon 2060}

Ce document présente des scénarios à long terme sur les échanges dans l'économie mondiale jusqu'en 2060, selon une approche de modélisation qui associe des prévisions globales de croissance dans le monde et un modèle d'équilibre général calculable détaillé pour les échanges sectoriels. L'analyse fait apparaître que le centre géographique des échanges continuera de se déplacer dans les 50 prochaines années de la zone de l'OCDE vers des régions hors OCDE dont la croissance plus rapide est ainsi mise en évidence. L'importance relative des régions sur les différents marchés à l'exportation devrait évoluer considérablement dans le demi-siècle à venir, les économies émergentes gagnant des parts des marchés à l'exportation de produits manufacturiers et de services. La libéralisation des échanges, en particulier la suppression progressive des droits de douane, des obstacles réglementaires aux échanges de services et du soutien à l'agriculture, ainsi que la baisse des coûts de transaction sur les produits pourraient se traduire par une hausse des échanges et du PIB à l'échelle mondiale. Les scénarios spécifiques de libéralisation régionale dans un noyau de pays de l'OCDE ou de libéralisation multilatérale partielle pourraient entrainer respectivement des hausses de $4 \%$ et de $15 \%$ des échanges et de $0.6 \%$ et $2.8 \%$ du PIB par rapport au statu quo. Enfin, le modèle fait ressortir le rôle de l'investissement en faveur de l'éducation dans les tendances des échanges et de la spécialisation à haut niveau de qualification dans les décennies à venir. Si le relèvement des niveaux d'instruction dans les grandes économies émergentes était plus lent que ne le prévoit le scénario de référence, les exportations mondiales pourraient être réduites de $2 \%$ en 2060 . Un renforcement moins sensible des compétences dans ces économies freinerait aussi leur redéploiement vers des activités à plus forte valeur ajoutée.

Classification JEL: E23, E27, F02, F17, F47

Mots-clés: Modèle général d'équilibre pour les échanges, tendances à long-terme des échanges et de la spécialisation, libéralisation des échanges. 


\section{TABLE OF CONTENTS}

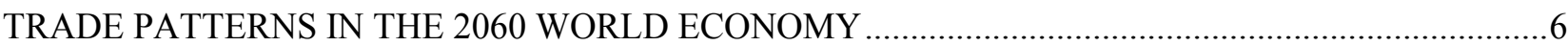

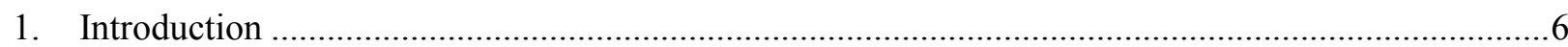

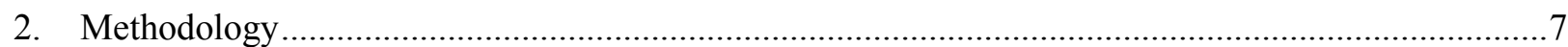

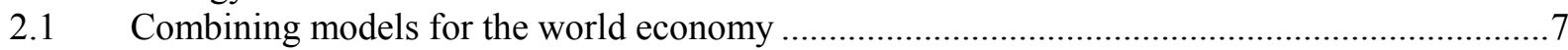

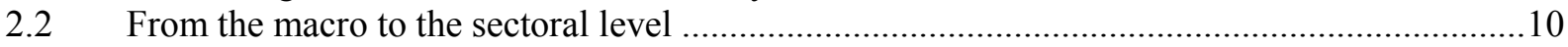

3. Trade liberalisation scenarios and education baseline alternative ...................................................14

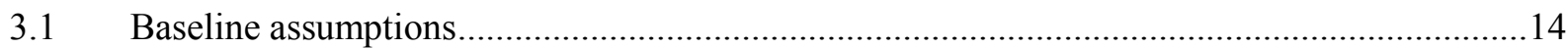

3.2 Trade liberalisation scenarios: Regionalism versus multilateralism.......................................16

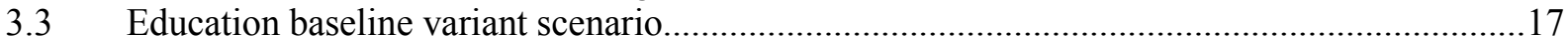

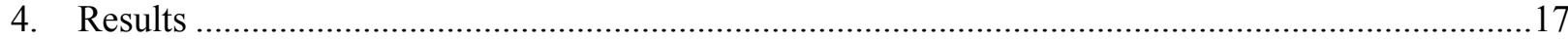

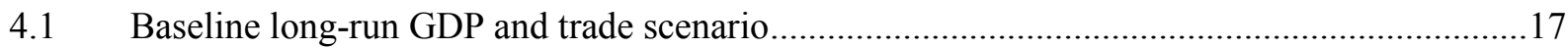

4.2 Trade liberalisation can increase global trade and growth .................................................24

4.3 The speed of up-skilling in emerging economies influences GDP, trade and specialisation ....33

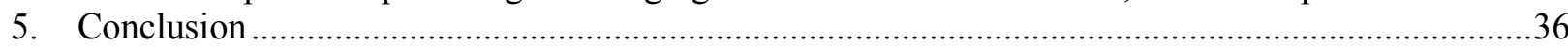

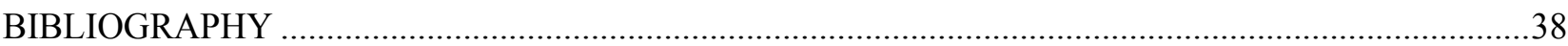

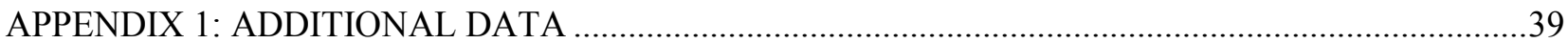

\section{Tables}

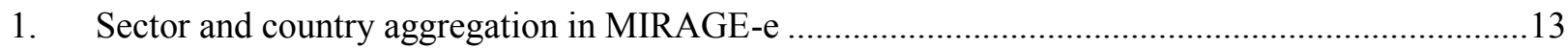

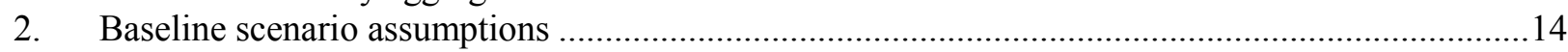

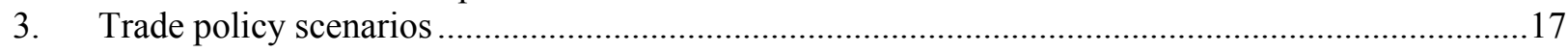

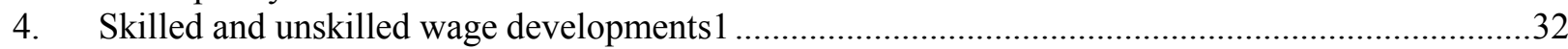

\section{Figures}

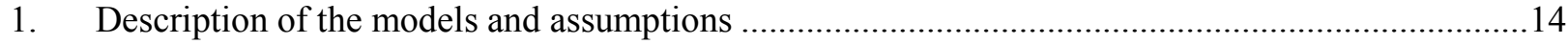

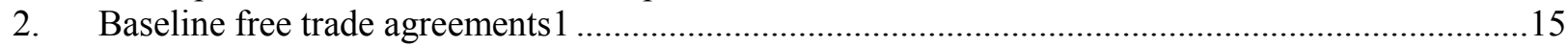

3. Growth of GDP, exports in goods and services and income-elasticities, 2012-20601 …...............16

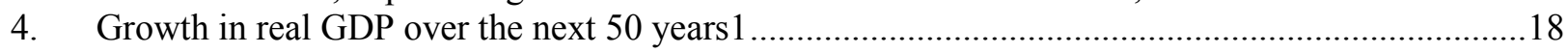

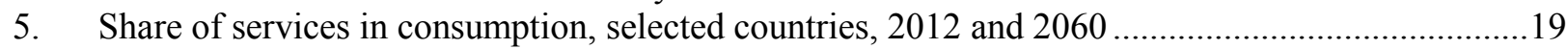

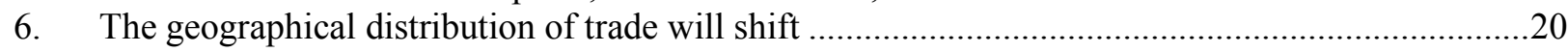

7. A growing share of trade will occur between different non-OECD countries ..............................20

8. The relative importance of different countries in specific industries are expected to change ..........22

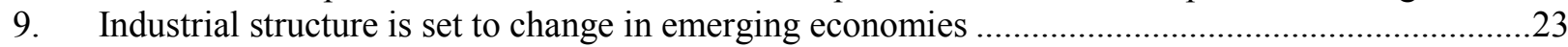

10. Growth in GDP, exports of goods and services, 2012-2060 ..................................................25

11. Unevenly distributed increases in trade in liberalisation scenarios, 2060 ...................................26

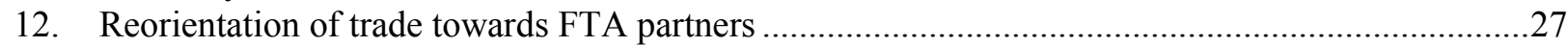

13. Export specialisation in manufactured products, 2060, volume …................................................28

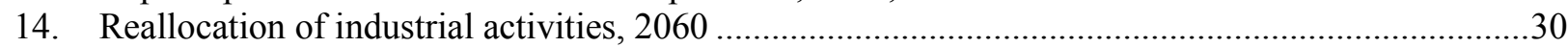

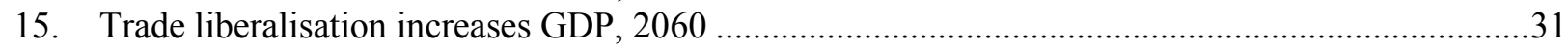

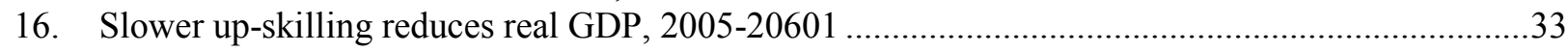


17. Effects on trade of lower upskilling in emerging economies, 2060 .34

18. Slower upskilling in CIIeconomies slows down restructuring towards higher skilled activities ......35

19. Production prices: Selected sectors, 2060 .36

A.1. Trade shares in selected industries, 2010 and 2060 


\title{
TRADE PATTERNS IN THE 2060 WORLD ECONOMY
}

\author{
By \\ Jean Château, Lionel Fontagné, Jean Fouré, Åsa Johansson and Eduardo Olaberría ${ }^{1}$
}

\section{Introduction}

1. Global trade is undergoing rapid change through a fragmentation of production processes and the integration of emerging economies into the global market. These trends are affecting trade and industrial specialisation around the globe. To explore likely changes in global trade and specialisation patterns at the 2060 horizon, this paper combines the modelling of the aggregate growth trajectories of individual countries with a detailed modelling of global trade relationships and trade barriers at the sectoral level. Growth trajectories for the 34 current OECD economies and 8 non-OECD G20 emerging countries rely on projections from the OECD long-term scenario model (Johansson et al., 2013) and are consistent with the long-term OECD Economic Outlook baseline (OECD, 2013), while projections for another 105 countries are based on CEPII's MaGE model (Fouré et al., 2012, 2013). CEPII's and OECD's long-term growth models rely on conditional convergence, in which each country is expected to converge to its own steadystate in the long-run. The projections account for the main structural factors affecting potential growth in the future: socio-demographic dynamics, human and physical capital accumulation and productivity developments. The CEPII and OECD models differ in some aspects. The OECD model highlights the link between structural policies and growth determinants, while the CEPII model emphasizes energy use and efficiency as well female labour force participation. The OECD and CEPII growth projections are made consistent to obtain a baseline growth trajectory for 147 countries in real terms.

2. The paper then analyses how world trade and specialisation patterns will evolve along this baseline growth trajectory. To this end, country-specific baseline growth trajectories are used to design a dynamic baseline for a multisectoral CGE model of the world economy, MIRAGE-e (Fontagné et al., 2013). In addition to calibrating the CGE model to reproduce the baseline trajectories for GDP, saving and current account imbalances, the CGE dynamic baseline includes a detailed modelling of the sector-specific trajectory of productivity (in agriculture, manufacturing and services). Energy demands in the baseline are calibrated on the IEA scenario of future fossil energy prices. This way, MIRAGE-e provides a baseline projection for the allocation of production across sectors, for bilateral and sectoral trade flows, as well as for factor incomes. Whereas the baseline growth trajectories are country-specific (though with a constraint on the global investment-saving balance), the CGE baseline projections are defined at the regional level. The countries included in MIRAGE-e are aggregated into 26 regions or country groupings based on a

1. Corresponding authors are: Jean Château from the OECD Environment Directorate, Lionel Fontagné from Paris School of Economics and the Centre d'Etudes Prospectives et d'Informations Internationales (CEPII), Jean Fouré from the Centre d'Etudes Prospectives et d'Informations Internationales (CEPII) and Åsa Johansson and Eduardo Olaberría from the OECD Economics Department. The authors would like to thank Jorgen Elmeskov, Giuseppe Nicoletti, Frank van Tongeren and Jean-Luc Schneider for their valuable comments and suggestions and Sarah Michelson for excellent editorial support. The paper has also benefited from comments by members of Working Party No. 1 of the OECD Economic Policy Committee. 
detailed description of the economy of each region, with two categories of labour (skilled and unskilled) and 25 sectors.

3. Once this baseline growth trajectory and dynamic CGE baseline projection for the world economy has been constructed, the paper analyses two stylised trade liberalisation scenarios and an alternative baseline assuming slower accumulation of human capital in three Asian emerging economies, to explore repercussions on growth, specialisation, trade and relative wages of skilled and unskilled labour. Two trade scenarios, a partial multilateral liberalisation and a full regional liberalisation, are compared with the baseline to explore in each case the impact on trade patterns and income distribution across skill levels.

4. The partial multilateral scenario assumes that world economies pursue a level-playing field for trade in goods and services, further cutting tariffs on goods on a multilateral basis, decoupling agricultural subsidies in all OECD countries, reducing non-tariff frictions to trade in goods, and letting regulatory obstacles to trade in services partially converge to those remaining in the EU in 2004. No assumption is made regarding the success or failure of the current Round of multilateral negotiations. Evolutions in tariffs, non-tariff barriers and frictions are considered to be the outcome of negotiation within the multilateral framework.

5. The full regional liberalisation scenario assumes developed economies firstly embark in an ambitious regional agreement (implemented progressively) fully phasing out tariffs, reducing regulatory obstacles to trade in services and frictions to trade in goods as above, but without decoupling of agricultural subsidies. This first phase of regionalism starting in 2014, would be extended to several other non-OECD countries from 2030 on, whereby major developing economies would embark in this liberalisation as well, though with less ambition regarding tariffs. In such regional scenario, only 38 economies of the world (European Union, Canada, the United States, Mexico, EFTA members, Australia, New-Zealand and Japan) are engaged in the full facilitation of trade in goods and services.

6. The remainder of this paper first describes our modelling approach and methodology in Section 2 , while Section 3 describes in detail the assumptions underlying the baseline, the two trade policy scenarios and the alternative baseline with slower skill accumulation in emerging economies. Section 4 presents the results from the modelling exercise and Section 5 concludes.

\section{Methodology}

7. OECD long-term macroeconomic projections for 42 countries are combined with CEPII longterm projections for the remaining 105 developing economies. These projections provide a consistent set of country-specific variables to be introduced in a CGE: GDP, saving rates, skilled and unskilled labour supply, current account balances and energy efficiency. In addition, a common set of exogenous variables is used regarding demography, human capital and energy prices. These macro projections are used to draw scenarios for trade patterns at the 2060 horizon for the world economy split into 26 regions/countries and 25 sectors.

\subsection{Combining models for the world economy}

\section{The OECD long-term model}

8. The growth model developed by the OECD, documented in Johansson et al. (2013), is used to project growth to 2060 for the 34 OECD members and 8 non-OECD G20 members. It derives potential output from a Cobb-Douglas production function featuring physical capital, human capital and labour. The two latter production factors are subject to a common technical progress. 
9. While population projections are exogenous (from Eurostat and United Nations Population databases), labour force participation rates are projected using a cohort approach. In practice the cohort approach assumes that the observed participation behaviour of individuals belonging to the most recent cohorts will continue in the future and this amounts to juxtapose constant age- and gender-specific entry and exit rates (varying with educational attainment). Special treatment is provided for retirement age, which embodies current and planned pension reforms and is indexed to changes in life expectancy over the long run, so as to maintain a constant share of active lives. Unemployment is assumed to converge towards the long-term level of unemployment (which is chosen to be the lowest level of Non-Accelerating Inflation Rate of Unemployment, NAIRU, between 2007 and 2013), at country-specific speeds that depend on labour market policies. Human capital is measured by average years of schooling of the adult population. Educational attainment of cohorts aged 25-29 is assumed to slowly converge to current best practice (Korea) over the long run at the average speed observed globally over the period 1960-2005, with attainment in Korea also gradually improving. Future educational attainment of the adult population is then projected using a perpetual inventory model and this projected stock of average years of schooling is converted into a measure of human capital assuming decreasing returns to education.

10. Total factor productivity (TFP) dynamics are governed by an estimated error-correction model featuring conditional convergence. TFP projections are driven by the global rate of technological progress and the speed of "catch-up" towards the country-specific steady-state level of TFP. Specifically, the country-specific long-run TFP level depends on the common global pace of technological progress and the country's regulations in product markets. The speed of convergence towards this long-run TFP level is country-specific as it depends on the degree of openness to trade. Greater openness to trade increases the speed of convergence towards the technological frontier, thus enhancing TFP growth.

11. Since in most developed economies, the ratio of capital to trend output has been relatively stable, the underlying projection for capital assumes a continuation of this stability in capital intensity. ${ }^{2}$ The projections of the underlying capital-output ratio are then subject to influences from the real cost of capital, which varies mainly due to changes in real interest rates. Saving rates are estimated as a function of oldage and youth dependency ratios, life expectancy, fiscal balances, terms of trade, productivity growth, net oil balances and the availability of credit. Projected investment and saving patterns determine residually current account balances for the 42 countries covered.

12. A closure rule imposes a constant overall saving-investment imbalance for the 42 countries. Deviations from such rule are reflected in changes of world interest rates that change the country-specific equilibrium capital stocks via the cost of capital. Other equilibrating mechanisms include risk premia on excessive public and external indebtedness, which also affect the country-specific costs of capital.

13. Policy-wise, the OECD baseline trajectory assumptions include:

- gradual convergence over the long-run in product market regulations and institutions towards settings currently found in the average OECD country;

- stabilisation of debt levels at $60 \%$ of GDP in countries with initial debt in excess of $60 \%$ while in countries with debt below $60 \%$, debt is stabilised at the current level;

- gradual increase over the long-run in financial market development to the current level in the United States, and;

2. There are a number of countries where capital intensity has shown a definite recent trend, and where this is the case, the trend is assumed to gradually disappear so that the underlying capital-output ratio stabilises. 
- gradual increase over the long-run in social spending in emerging economies to provisions similar to the average OECD country.

\section{MaGE: CEPII's long-term model}

14. Projections for 105 additional developing countries are obtained with the MaGE model proposed in Fouré et al. (2012, 2013). Based on a three-factor (capital, labour, energy) and two-technical progress (capital-labour and energy-specific) production function, MaGE is a supply-side oriented macroeconomic growth model, defined at country level for 147 countries (although only 105 are covered in this projection exercise as the other are covered by the OECD projections). It was built in three steps: production factor and productivity data were collected for the 1980-2009 period drawing on World Bank, United Nations and International Labour Organization data; behavioural relations for factor accumulation and productivity growth were estimated; and these relations were used to project GDP.

15. Supply is modelled as a CES production function of energy and a Cobb-Douglas bundle of capital and labour. In MaGE, technological progress includes energy efficiency and TFP. It is derived theoretically, and estimated econometrically at the macroeconomic level.

16. Behavioural relations are estimated for the education level, female participation to the labour force, capital accumulation and the two forms of efficiency improvements. The labour force projection starts from UN population projections, split across 5-year age groups. For each of these age groups, education is estimated and labour force participation is derived in the following way. While male labour force participation follows the logistic relation determined by the International Labour Organization projections (and therefore does not depend on education), female participation is assumed to change with education level (more education means less participation for the study-age women, while it enhances participation afterwards). Educational attainment, defined as the percentage of each age group having attained a secondary or tertiary diploma, is assumed to follow a catch-up process to the leaders. The catching-up has different speeds, depending on the region and age-group, while the leader levels for each age-group and educational level are composites of the different leader countries (i.e. Austria, Japan, the United States, Switzerland, France, Norway, New-Zealand and Russia, depending on the education level and time period). In turn, these best-practice targets are assumed to continue to grow at their historical pace.

17. Investment in MaGE is a function of savings. It is modelled as a non-unitary error-correction relationship that differentiates long-term correlation between saving and investment and annual adjustments around this trend. Saving is a function of economic growth and the age structure of the population, consistent with the life-cycle hypothesis. Capital accumulates in MaGE according to a permanent-inventory process with a constant depreciation rate. The closure rule in MaGE imposes consistency between saving and investment at the global level.

18. Capital-labour TFP and energy efficiency are driven by catch-up to the best-performing countries. TFP catch-up is conditional on, and driven by, the educational level, while tertiary education fuels innovation (autonomous productivity improvements), secondary education is a prerequisite for imitation (catching-up). Energy efficiency catch up depends both on the distance to the technological frontier in energy use, and on the level of development, to reflect differences in sectoral structure across countries. $^{3}$

3. At early stages of development, economies rely largely on agricultural production, which is not very energy-intensive, while industrialisation leads to an intensification of energy use and the later change towards services reverses the trend. Conditioning the energy-efficiency catch-up to the level of development allows representing this stylised fact at the macro level. 


\section{Consistency between OECD and CEPII models}

19. The OECD and MaGE modelling frameworks share certain essential characteristics (production function approach, conditional convergence, life-cycle savings, closure rule, etc.) but also differ in many respects. This partly reflects the different coverage of countries - with OECD projecting growth for advanced and major emerging economies and MaGE projecting growth for a larger set of countries for which data may be scarce - and different focus - with OECD projections highlighting the role of policies and looking also at fiscal balances and MaGE projections giving a more detailed account of catching up processes in terms of education, female participation, energy efficiency and addressing the role of oil rents in determining GDP changes of major oil exporters. Projections with MaGE are also less demanding in terms of data, which facilitates the extension of the exercise to a larger set of countries. In sum, the OECD and MaGE are broadly similar but each is best suited to deal with advanced and developing economies, respectively. In view of differences in specification, particular care has been taken to exploit the complementarity and ensure consistency of the two sets of projections.

20. In practice, projections of GDP, labour force, education and current accounts for the 42 countries covered by the OECD long-term model are used as an input for MaGE. Some variables that are not available in OECD projections or not suited for MaGE specification are derived according to MaGE's estimated relationships. TFP for the 42 OECD and non-OECD G20 countries is recovered as the gap between the projected production factors (capital, labour and energy) and the GDP projected by the OECD model, but encompassing the effect of human capital accumulation in the technical progress. ${ }^{4}$ For the remaining 105 countries, productivity levels, production factors and GDP are recovered using MaGE assumptions. Investment in the 105 countries adjusts to match the saving-investment balance at the global level. This ensures consistency between the closure rules of the two models, as the overall imbalance for the 42 countries covered by the OECD model is compensated by a symmetric overall imbalance for MaGE's 105 countries, with the global surplus or deficit of investment distributed to these latter countries proportionally to their contribution to global pre-rescaling investment levels.

\subsection{From the macro to the sectoral level}

21. The multi-sectoral CGE model has a recursive sequential dynamic set-up that is fed with the output of the OECD and MaGE aggregate growth models. Projections from these models are used to construct a dynamic baseline for MIRAGE-e (Fontagné et.al, 2013; Decreux and Valin, 2007). MIRAGE-e relies on the same exogenous variables (population, energy prices) that are embodied in the macroeconomic models, but takes as additional exogenous variables the results from the macroeconomic projections, notably GDP, saving rates, current accounts, labour force, human capital formation and energy efficiency. Moreover, the distribution of human capital in the population is used to set the number of skilled and unskilled workers in MIRAGE-e, which distinguishes these two categories of labour, with the assumption that skilled workers correspond to people having obtained a tertiary level diploma. The global closure of MIRAGE-e is ensured by imposing that the share of each country/region in the global current account imbalance varies yearly according to the macro projections.

\section{Supply in MIRAGE-e}

22. On the supply side, each sector in MIRAGE-e is modelled as a representative firm, which combines value-added and intermediate consumption in fixed shares. Value-added is a bundle of imperfectly substitutable primary factors (capital, skilled and unskilled labour, land and natural resources) and energy. Firms' demand for production factors is organised as a Constant Elasticity of Substitution (CES) aggregation of land, natural resources, unskilled labour, and a bundle of the remaining factors. This

4. The technical frontier in MaGE is not affected by this redefinition (see Section 2.2). 
bundle is a nested CES aggregate of skilled labour, and another bundle of capital and energy. Finally, energy is a CES aggregate of energy sources (except for non-electricity energy production sectors, for which the share of each energy input is fixed). Energy consumption of the representative firm comprises five energy goods (electricity, coal, oil, gas and refined petroleum), which are aggregated in a single bundle that mainly substitutes for capital.

23. MIRAGE-e assumes full employment of primary factors, whose growth rates are set exogenously based on the macro projections on a yearly step, as detailed below. ${ }^{5}$

- Population, participation in the labour market and human capital evolve in each country (or region of the world economy) according to the demographics embedded in the macro projections. This determines the labour force as well as its skill composition (skilled/unskilled). ${ }^{6}$ Skilled and unskilled labour is perfectly mobile across sectors, but immobile between countries.

- Natural resources are sector specific, while land is mobile not only between agricultural sectors but also between agriculture and other uses. Natural resources for the mining sector and land for agricultural sectors are set at their 2004 levels: prices adjust demand to this fixed supply. In the baseline, natural resources for fossil fuel production sectors adjust to match the imposed exogenous price target (taken from the International Energy Agency, 2012) for coal, oil and gas, and according to the energy demand projected by the model. By contrast, in the simulations, changes in demand for fossil energy sources influence their price, while natural resources are fixed at their baseline level.

- Installed capital is assumed to be immobile (sector-specific), while investments are allocated across sectors according to their rates of return. The overall stock of capital evolves by combining capital formation and a constant depreciation rate of capital of $6 \%$ that is the same as in the long-term growth models. Gross investment is determined by the combination of saving (the saving rate from the growth model, applied to the national income) and the current account. Finally, while total investment is saving-driven, its allocation is determined by the rate of return on investment in the various activities. For simplicity, and because of lack of reliable data on foreign direct investment at country of origin, host and sectoral levels, international capital flows only appear through the current account imbalances, and are not explicitly modelled.

\section{Demand in MIRAGE-e}

24. On the demand side, a representative consumer from each country/region maximises instantaneous utility under a budget constraint and saves a part of its income. Expenditure is allocated to commodities and services according to a LES-CES (Linear Expenditure System - Constant Elasticity of Substitution) function. This implies that, above a minimum consumption of goods produced by each sector, consumption choices among goods produced by different sectors are made according to a CES. This representation of preferences is well suited to the analysis as it is flexible enough to deal with countries at different levels of development.

25. Within each sector, goods are differentiated by their origin. A nested CES function allows for a particular status for domestic products according to the usual Armington hypothesis (Armington, 1969): consumers' and firms' choices are biased towards domestic production, and therefore domestic and foreign

5. Accordingly, unemployment is only captured via its short-term impact on GDP of the 42 countries covered by OECD long-term projections, which is then reported in the endogenous TFP of MIRAGE-e.

6.

In MIRAGE-e, contrary to MaGE, no gender distinction is made. 
goods are imperfectly substitutable, using a CES specification. Armington elasticities (defined at sector level but common to all regions) are recovered from the GTAP database (Global Trade Analysis Project) and estimated by Hertel et al. (2007). Total demand is built from final consumption, intermediate consumption and investment in capital goods.

26. Efficiency in the use of primary factors and intermediate inputs is based on the combination of four mechanisms. First, agricultural productivity is projected separately, as detailed in Fontagné et al. (2013). Second, energy efficiency computed from the aggregate growth models is imposed on MIRAGE-e (it enters the capital-energy bundle). Third, a 2 percentage point growth difference between TFP in manufactures and services is assumed (as in van den Mensbrugghe, 2005). Fourth, given the agricultural productivity and the relation between productivity in manufacturing and services, MIRAGE-e recovers endogenously country-specific TFP from the exogenous GDP and production factors. Notice that TFP thus recovered from the baseline projections is subsequently set as exogenous in the alternative scenarios. Therefore, GDP becomes endogenous in such scenarios.

27. Dynamics in MIRAGE-e is implemented in a sequentially recursive way. That is, the equilibrium can be solved successively for each period, given the exogenous variations of GDP, savings, current accounts, active population and skill level coming from the growth models, as described above. For baseline projections, the time span is 56 years, the starting point being 2004 .

28. MIRAGE-e was calibrated on the GTAP dataset version 7, with 2004 as a base year. As shown in Table 1, our data aggregation singles out all energy industries and combines other industries into main representative subsectors within the agriculture, manufacturing and services aggregates. For the regional aggregation, the main OECD member countries are retained, while other member countries are aggregated. Main emerging economies are also isolated whereas the rest of the world is aggregated on a geographical basis. Table 1 shows the composition of regions, highlighting which of them is fully described in the OECD long-term aggregate growth projections. For instance, all countries in the euro area, considered as a region in MIRAGE, were modelled individually using the OECD macroeconomic framework. In contrast, only one country (Israel) in the Middle-East region of MIRAGE was modelled by the OECD. Finally, North Africa is an example of region in MIRAGE which has been modelled exclusively by MaGE. 
ECO/WKP(2014)38

Table 1. Sector and country aggregation in MIRAGE-e

\begin{tabular}{|c|c|}
\hline Regions & Sectors \\
\hline OECD countries & Primary \\
\hline Euro Area* & Crops \\
\hline United Kingdom* & Livestock \\
\hline European Free Trade Agreement* & Other Agriculture \\
\hline Rest of European Union* & Other Primary \\
\hline Turkey* & Energy \\
\hline United States* & Coal \\
\hline Canada* & Oil \\
\hline Mexico* & Gas \\
\hline Chile* $^{*}$ & Electricity \\
\hline Japan* & Refined petroleum \\
\hline South Korea* & Manufacturing \\
\hline Australia and New Zealand* & Food \\
\hline Non-OECD countries & Textile \\
\hline Russian Federation* & Paper and publishing and Wood Products \\
\hline Rest of Europe & Chemicals, rubber and plastics \\
\hline Middle-East $^{+}$ & Iron and Steel \\
\hline North Africa & Metals \\
\hline South Africa* & Metal products \\
\hline Other African countries & Transport Equipment \\
\hline Brazil $^{*}$ & Electronic devices \\
\hline Other Latin America $^{+}$ & Other Minerals \\
\hline China* $^{*}$ & Other Manufacturing \\
\hline India* & Services \\
\hline Indonesia* & Trade \\
\hline Other ASEAN countries & Transport \\
\hline Other Developing Asia & Finance, Insurance and Business Services \\
\hline \multirow[t]{2}{*}{ Caspian } & Public Administration \\
\hline & Other services \\
\hline
\end{tabular}

${ }^{*}$ Regions fully included in the 42 OECD sample.

${ }^{+}$Regions with one country only in the 42 OECD sample (Argentina and Israel)

29. Tariff data at the HS6 level corresponds to the ad valorem equivalents from the MAcMap HS6 database (Guimbard et al., 2012) and are aggregated to match our regional and sectoral decomposition using the reference group methodology (Bouët et al., 2008). Finally, the model includes international transaction costs and non-tariff measures (NTM) in services, modelled as an iceberg trade cost (i.e. cost of transporting a good that uses up a fraction of the good). Data for trade costs associated with delays were calibrated using a database provided by Minor and Tsigas (2008), who adopt the methodology in Hummels and Schaur (2012). NTM in services are ad valorem equivalents taken from Fontagné et al. (2011).

30. The way in which the OECD long-term model, MaGE and MIRAGE-e are related is summarised in Figure 1, which shows the different variables that the models exchange and the point at which assumptions are introduced (see Section 3 for details). Notice that two alternative sets of assumptions on educational catch-up lead to two alternative baseline scenarios. Accordingly, two alternative baselines are compared in the education scenario. However, trade liberalisation scenarios (regionalism versus multilateralism) are implemented as trade policy shocks in the baseline with high education only. Details on assumptions underlying these simulations are described in the next sections. 
Figure 1. Description of the models and assumptions

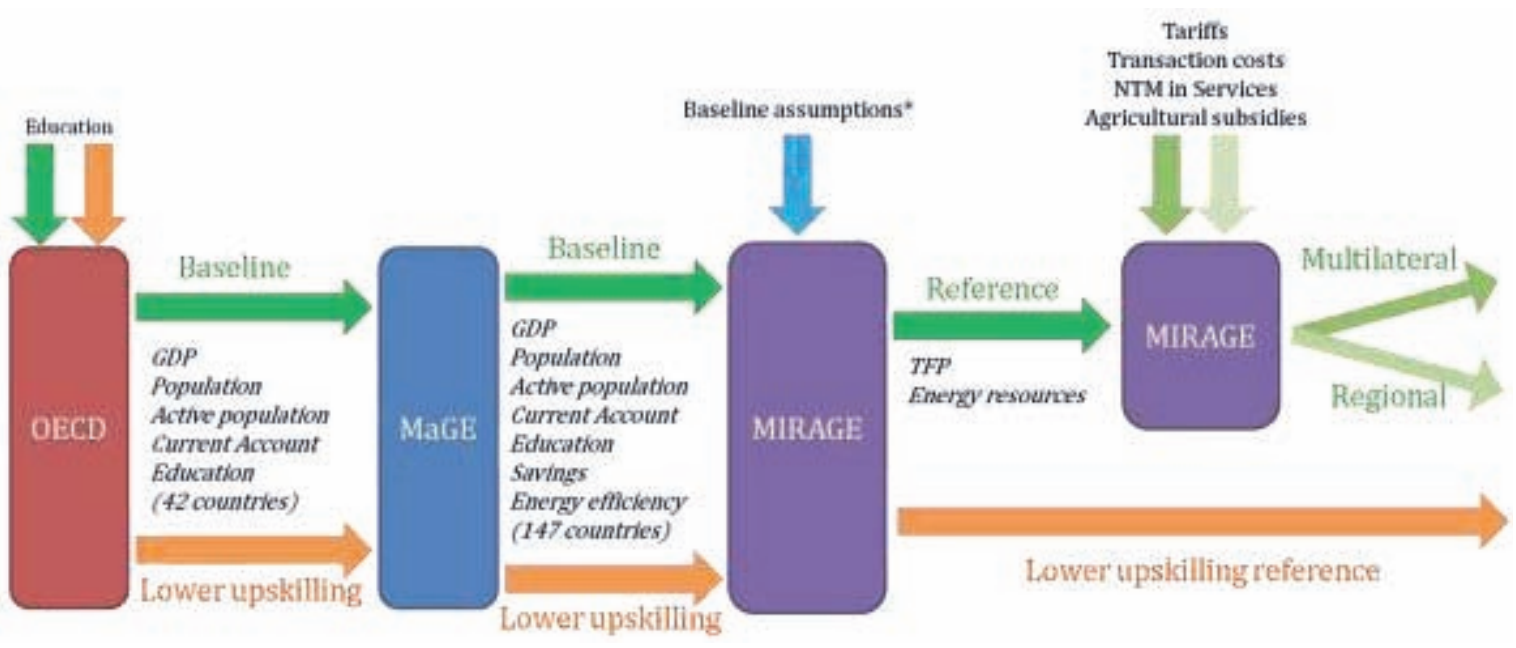

Note: Vertical arrows show scenario assumptions, while horizontal arrows indicate variable flows between the models.

*See Table 2.

\section{Trade liberalisation scenarios and education baseline alternative}

31. The main objective of this paper is to investigate the driving forces of trade and specialisation patterns at the 2060 horizon. In order to do this a coherent baseline scenario for the world economy is constructed, based on the evolution of major determinants of growth (such as demography, physical and human accumulation and energy availability). This framework integrates available information on preferential trade agreements already signed. After calibrating MIRAGE-e in order to reproduce the longterm trade to income elasticities projected in the growth baseline trajectory, we obtain a baseline for the CGE that is shocked using the two scenarios already mentioned: full regional trade liberalisation versus partial multilateral liberalisation.

\subsection{Baseline assumptions}

32. When projecting trade patterns, it is important to rely on a model that is able to reproduce some basic stylised facts such as the trade-to-income elasticity. Here we follow the methodology described in Fontagné and Fouré (2013) to make the model mimic this elasticity. As shown in Table 2, four main drivers of this elasticity are tariffs, fossil-fuel energy prices, transaction costs for goods and TFP in the transportation sector. While energy prices are drawn from the International Energy Agency projections to 2035 (these are extended linearly to 2060 in MIRAGE), the three remaining parameters need to be calibrated to reproduce past evolutions of world trade.

Table 2. Baseline scenario assumptions

\begin{tabular}{ll}
\hline Variable & Baseline assumption \\
\hline Energy prices (Coal/Oil/Gas) $^{\mathrm{a}}$ & $\mathrm{IEA}(2012)$ \\
Transaction costs for goods $^{\mathrm{a}}$ & $-25 \%$ in $2035(-45 \%$ in 2060$)$ \\
TFP in transports $^{\mathrm{a}}$ & $+2 \%$ annual growth (compared to services) \\
Free Trade Agreements & EU28/ASEAN and partners \\
New Common Agricultural Policy & $-75 \%$ factor subsidy in EU in 2005 (Crops and Other Agriculture) \\
& $-50 \%$ factor subsidy in EU in 2005 (Livestock) \\
\hline
\end{tabular}

a Source: Fontagné and Fouré (2013). 
33. Determining a reference scenario for drivers such as transaction costs or TFP in the transportation sector is a difficult exercise, as they summarise a large variety of determinants. Productivity in transports encompasses breakthroughs like containerisation. Product standards also influence the transaction costs (approximated here by the tariff-equivalent of time spent in duties), along with the administrative organisation of duties and other related factors.

34. To proceed, the four drivers are calibrated using trajectories similar to those observed over the past 50 years. This implies adding a $2 \%$ additional TFP growth in transportation (compared to other services), in line with estimations by Wolff (1999) on years 1958-1987. Finally it is necessary to calibrate a $25 \%$ decrease in transaction costs for goods, to recover a long-term elasticity in line with the observed one.

35. Then, since the trade liberalisation scenarios will consider scenarios on agricultural subsidies, the implemented reforms of the Common Agricultural Policy (CAP) of the European Union acted in 2003 and taking into effect in 2005 are incorporated in the model. This is done in a simplified form (due to the sectoral aggregation), based on Gouel and Laborde (2007).

36. Finally, the MIRAGE-e baseline includes Free Trade Agreements (FTA) that are already planned at the time of writing, using the WTO database on regional trade agreements. This results in two FTAs (enlargement of the European Union to 27 and then 28 members, plus implementation of the ASEAN treaties) and six bilateral regional agreements (between EU and Korea, and the so-called ASEAN+6 agreements). These agreements are implemented at the Harmonized commodity Description and Coding System 6 (HS6) level using MAcMap for 2004. The timing for implementation is summarised in Figure 2.

Figure 2. Baseline free trade agreements ${ }^{1}$

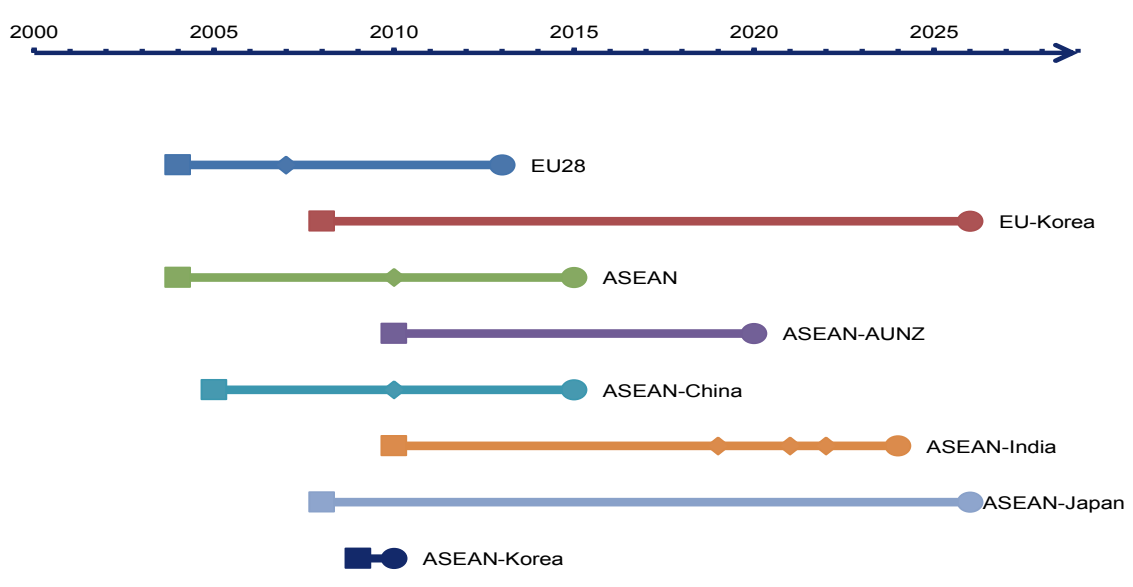

1. The Association of Southeast Asian Nations (ASEAN) consists of Indonesia, Malaysia, the Philippines, Singapore, Thailand, Brunei, Cambodia, Laos, Myanmar (Burma) and Vietnam. AUNZ denotes Australia and New Zealand.

37. The implementation of these FTAs is two-fold. ${ }^{7}$ First, it consists in the progressive abolition of tariff duties among the participants. For each step of each agreement, the tariff reduction is linearly implemented at the HS6 commodity level for all countries, and the results are aggregated to our mapping described in Table 1. Second, the external tariff (imposed on non-FTA members) of the FTA members is homogenised. Concerning the European Union, it is assumed that Croatia adopts pre-existing European tariffs in 2013, whereas for the ASEAN it is assumed that all members adopt the average tariff at the end of the implementation (2015).

7. The detailed implementation is available from the authors upon request. 
38. Together these assumptions imply that the model projects an elasticity of world trade to world GDP of around 1.4 for goods (as compared to 2.8 during the 1990's and to 1.6 between 1950 and 2009) and 1.2 for services (Figure 3). This lower elasticity for services is coherent with the assumptions, since the baseline projection does not include scenarios on NTM in services. This lower responsiveness of trade to GDP as compared to the one during the 1990s partly reflects that the intensity of fragmentation of global value chains that occurred in the last decades is hypothesised to slow down as there are likely physical limits on how much a product can be fragmented (Fontagné and Fouré, 2013).

Figure 3. Growth of GDP, exports in goods and services and income-elasticities, 2012-2060 ${ }^{1}$

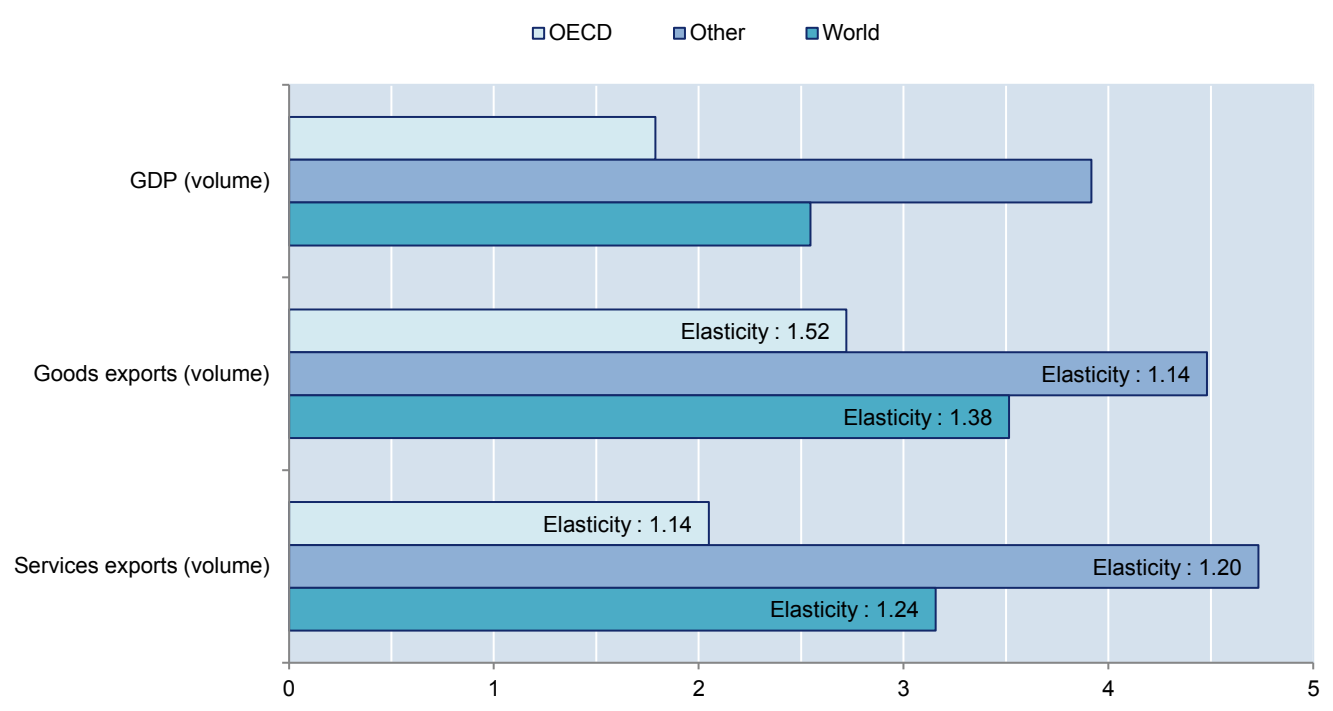

1. Goods and services exports including intra-trade.

\subsection{Trade liberalisation scenarios: Regionalism versus multilateralism}

39. Despite reductions in market- and non-market barriers to trade during the last decades, particularly for industrial products, significant barriers still remain at the global level. These barriers go beyond tariffs on goods. Regulatory obstacles to trade in services, agricultural subsidies and transaction costs on goods remain large. While trade liberalisation can take different forms, the approach in this paper is to describe two stylised alternative trade facilitation scenarios as summarised in Table 3 . In the partial multilateral liberalisation scenario, applied tariffs on goods are linearly halved and there is a further $25 \%$ reduction in international transaction costs relative to baseline. Moreover, outside the EU regulatory obstacles to trade in services partially converge towards current EU levels, while EU further implements its internal market for services (leading to a $10 \%$ decrease of barriers to trade in services among Member States over the long run). Coupled agricultural subsidies are phased out in the OECD, beyond Europe.

40. The full regional liberalisation scenario considers two horizons. The large FTA area comprising NAFTA, the European Union, Australia/New Zealand, Japan and Korea is completed by 2060. This is a long process, but the zone is very large and diverse. Some of its members are potentially attached to agricultural subsidies, which are eventually not phased out as opposed to the multilateral scenario. Tariffs are phased out, while progress in terms of market access for services and transaction costs is now limited to the borders of the FTA. From 2014 to 2030, trade liberalisation is strictly limited to the wide region sodefined. Then, from 2030 on, this region reduces tariffs on a bilateral and reciprocal basis with a series of preferred partners, including the BRICs, South Africa, ASEAN and Chile. Neither trade in services nor transaction costs are concerned. 
ECO/WKP(2014)38

Table 3. Trade policy scenarios

\begin{tabular}{|c|c|c|}
\hline Variable & Partial Multilateral liberalisation & Full Regional liberalisation \\
\hline Tariffs & $\begin{array}{l}-50 \% \text { in } 2060 \text { (compared to } \\
\text { baseline scenario) }\end{array}$ & $\begin{array}{l}-100 \% \text { in } 2060 \text { in the FTA area } \\
-50 \% \text { in } 2060 \text { with partners (from } \\
2030 \text { ) }\end{array}$ \\
\hline Transaction costs for goods & $-25 \%$ in 2060 & $-25 \%$ in 2060 in the FTA zone \\
\hline NTM in services & $\begin{array}{l}-10 \% \text { in } 2060 \text { among EU members. } \\
\text { Half convergence in } 2060 \text { to } \\
\text { average intra-EU level between } \\
\text { other countries. }\end{array}$ & $\begin{array}{l}-10 \% \text { in } 2060 \text { among EU members. } \\
\text { Half convergence in } 2060 \text { to } \\
\text { average intra-EU level for other } \\
\text { countries inside FTA area. }\end{array}$ \\
\hline Coupled agricultural subsidies & $\begin{array}{l}-50 \% \text { in } 2060 \text { for EU, USA, Japan, } \\
\text { Korea, Canada, EFTA. }\end{array}$ & No change \\
\hline
\end{tabular}

41. These scenarios are designed to allow for comparison between a full liberalisation between a small number of (developed mostly OECD) countries, along with bilateral agreements, and a liberalisation resulting from global multilateral negotiations, while keeping assumptions simple to be able to trace their implications. Indeed, a multilateral framework is likely to lead to a less ambitious agreement (as demonstrated by the tensions on the Doha agenda) both in terms of tariff reduction and non-tariff measures.

\subsection{Education baseline variant scenario}

42. Given that long-term growth trajectories are likely to be influenced by the skill distribution, as emphasised in Fontagné and Fouré (2013), it is worth comparing our central baseline with one in which skill developments are different. Since a more educated population is likely to influence TFP, the three steps constituting our modelling exercise (i.e. the OECD model, the MaGE and the MIRAGE baseline) are recomputed with a different configuration of skills (so-called lower up-skilling scenario). In this lower skill scenario, human capital upgrading in key emerging economies is weaker than in the baseline scenario.

43. Changes in the stock of human capital influence aggregate growth, especially in developing economies, and affect trade patterns across countries. Among the main developing countries, the Asian ones have exhibited large improvements in terms of human capital accumulation and technological progress (Fouré et al., 2012), while remaining at a relatively low level of productivity, leaving room for the large improvements that occur in our projections. Therefore, the low-skill scenario focus on the three largest Asian developing countries - China, India and Indonesia, hereafter called CII economies - and implement an alternative baseline in which the educational attainment of the cohort aged 25-29 will converge to the frontier level of education at a speed that is $50 \%$ slower than assumed in the baseline macro projections. As a result, by 2060 average years of schooling are around 1.2 years lower in these three countries as compared with the baseline.

\section{Results}

\subsection{Baseline long-run GDP and trade scenario}

\section{Global growth will be sustained by emerging economies}

44. Over the next half century, world GDP is projected to grow on average around $3 \%$ per year with declining rates in many countries. Up until 2030, world growth will be sustained by a rising weight of 
China and India with high, albeit declining, growth while after 2030 fast growth in Africa is expected to support world growth. The OECD trend GDP growth is projected at about $2 \%$ annually until 2050-2060, and growth in emerging economies will continue to outpace the OECD, but the difference will narrow over coming decades as income levels in emerging economies catch up to those in the OECD (Figure 4). As a result, the next 50 years will see major changes in the relative importance of countries or regions in global GDP.

Figure 4. Growth in real GDP over the next 50 years ${ }^{1}$

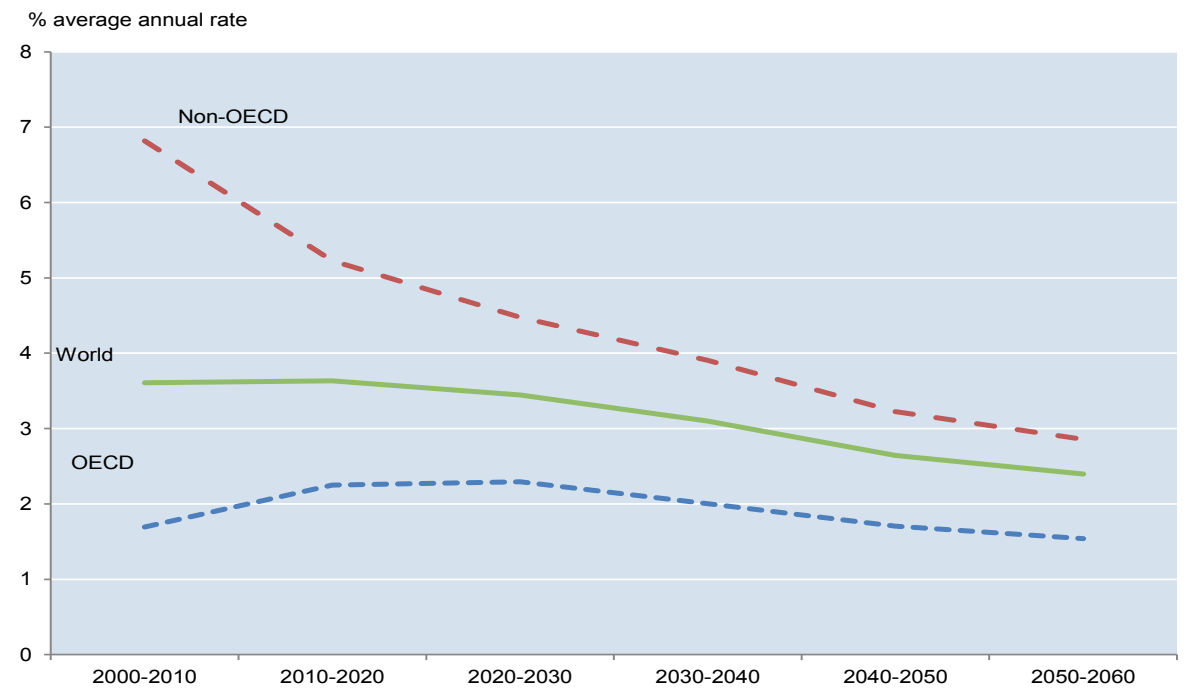

1. World GDP refers to 147 countries

45. Concerning the composition of GDP, two forces are at play. Relative prices change due to overall differences in TFP (relative prices of manufactured goods decrease) while, in developing countries, preferences shift toward services. By 2060, services will represent a lower share of world consumption but a higher share of consumption in developing economies (Figure 5). 
Figure 5. Share of services in consumption, selected countries, 2012 and $2060^{1}$

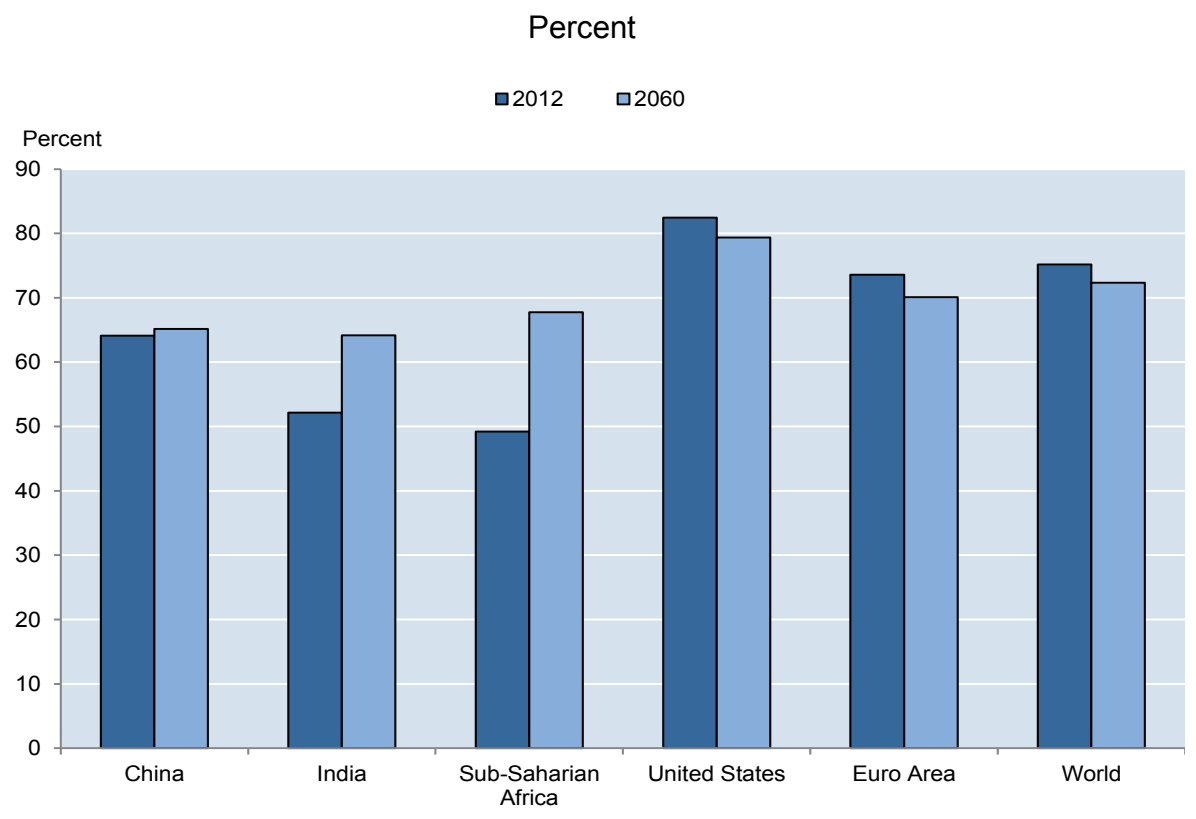

\section{Continuing globalisation over the next half century}

46. Growth in trade (gross exports of goods and services) is expected to continue to outpace GDP growth over the next 50 years with world trade estimated to grow at around 3.5\% annually (compared with $6.9 \%$ over the period $1990-2007)$.

47. In terms of geographical distribution, there will be large shifts in trade patterns, reflecting among other things uneven developments in income across the globe as well as changes in comparative advantages (Figure 6). China and India are projected to gain market shares in world trade over the next half century, although the rapid growth in China's trade share is expected to slow down after 2030, as GDP growth is slowing. Likewise, Africa, Indonesia and other Asian economies are projected to experience sizeable increases in trade shares, especially after 2030, reflecting rapid growth leading to larger economic size combined with low production costs. These gains in trade shares of emerging and developing economies are mostly at the expense of Euro area members. From having accounted for $19 \%$ of world exports in 2012, the Euro area's market share in exports is expected to fall to approximately $12 \%$ by 2060 . However, given the increase of world imports over that period, Euro area exports are expected to triple despite such reduced market share. By contrast, some OECD economies, including the United States and Canada, are projected to see their trade shares decrease only slightly, reflecting comparatively more favourable growth projections than the euro area. 
Figure 6. The geographical distribution of trade will shift

Gross exports as a share of world exports, \%

2012

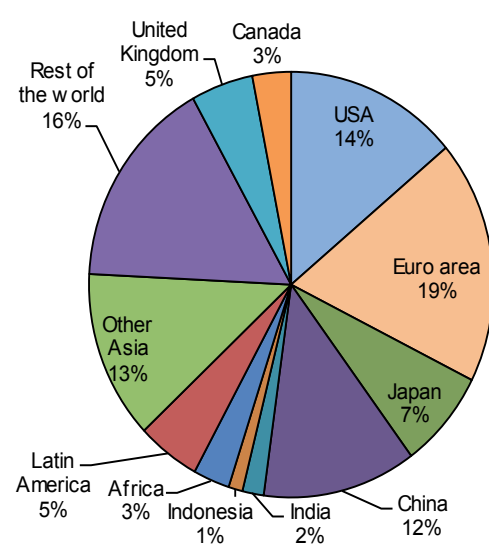

2030

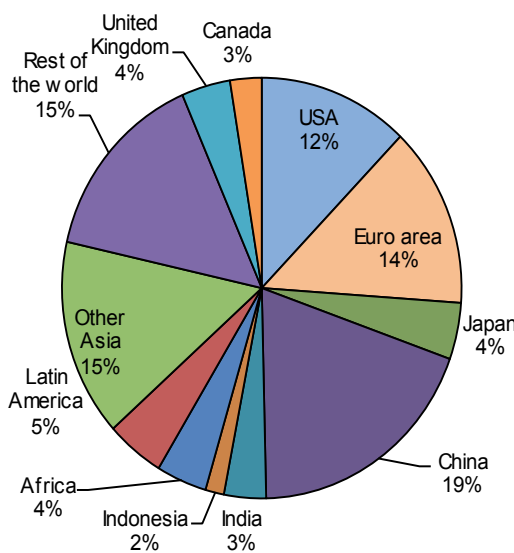

2060

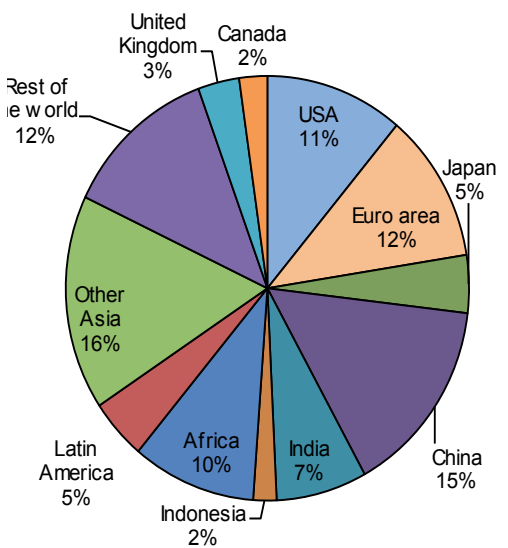

48. The changing geographical distribution of trade is matched by changes in the relative importance of different sets of trading partners (Figure 7). Trade volumes are driven, among other things, by gravity factors including size of economies, distance or language. Consistent with this, the projections of the CGE model suggest that the expected shift of wealth creation from OECD to non-OECD countries will have important implications for trade patterns. While in 2012 about half of total trade in bilateral terms took place within the OECD area, the importance of bilateral trade among OECD members is expected to nearly halve by 2060. Instead, by 2060 trade among non-OECD economies will more than double, to account for approximately one-third of global trade. For instance, trade among Asian economies increases from around $6 \%$ to $16 \%$ over the projection period. At the same time, OECD economies will increasingly import products from non-OECD economies, whereas the share of global imports of non-OECD from OECD countries will remain more or less unchanged. All in all, over the next 50 years the geographical centre of trade is projected to move away from OECD towards non-OECD countries.

Figure 7. A growing share of trade will occur between different non-OECD countries

Gross exports, \%

2012

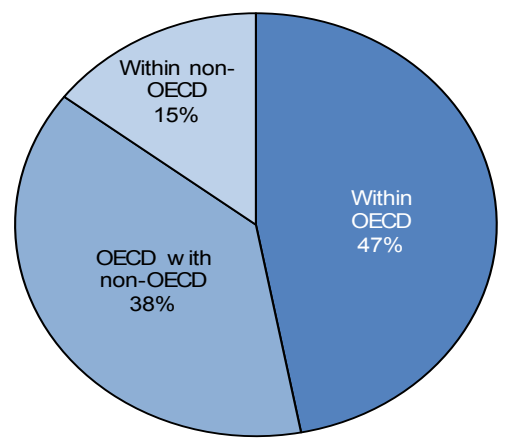

2060

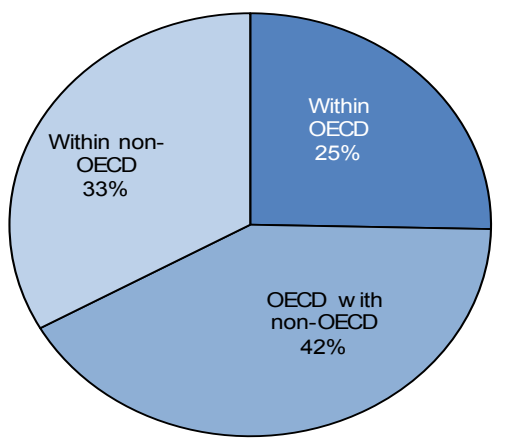




\section{Globalisation and income convergence will influence trade patterns}

49. The relative importance of different countries and regions in specific markets is set to change markedly over the coming decades, driven by diverging growth performance, changes in relative productivity and production prices as well as a reorientation of consumption in emerging economies towards services (Figure 8). Notably, China, India, other Asian economies and Africa are projected to become the dominant players in manufacturing, while most OECD countries are expected to lose ground. For instance, Japan, South Korea and the United States are set to lose their comparative advantage in electronics to China and other Asian countries (see Appendix 1, Figure A.1), who could account for as much as $70 \%$ of world exports in electronics by 2060 . However, the long-run trends for detailed sectors should be interpreted with caution, given that the model-based scenario cannot foresee and incorporate major shifts in consumer preferences or technological breakthroughs.

50. Emerging and developing economies' (e.g. China, India and Africa) world market shares will increase significantly even in service trade, as a result of a shift towards more advanced activities as these economies become wealthier, combined with a larger economic size. The gain in service trade shares in China and India is mostly at the expense of the Euro area, the United States, Japan and the United Kingdom. This tendency could be further reinforced by the possibility that some tasks performed by service sectors are offshored to low-wage countries.

51. In the energy sector, a marked shift in the global distribution of trade is expected to occur over the next half century. The trade share of the United States in world energy exports is expected to more than triple by 2060, at the expense of the Middle East and the Russian Federation. These large expected gains are consistent with recent investments in technologies to extract and develop new sources of shale gas and oil, as compared with the exhaustion of conventional natural reserves in other parts of the world (e.g. IEA, 2012). Alongside the increase in energy trade, the United States maintains competitiveness in complementary industries such as chemicals (see Appendix 1, Figure A.1). However, it should be noted that the energy sector is subject to large geopolitical and technological uncertainty over the next half century, making projections particularly vulnerable to unpredicted events.

52. In agriculture, the United States and other Asian countries are expected to remain competitive and their trade share in agricultural exports will increase mostly at the expense of Africa and Latin America. 
Figure 8. The relative importance of different countries in specific industries are expected to change ${ }^{1}$

Countries shares in world exports, 2010 and $2060 \%$

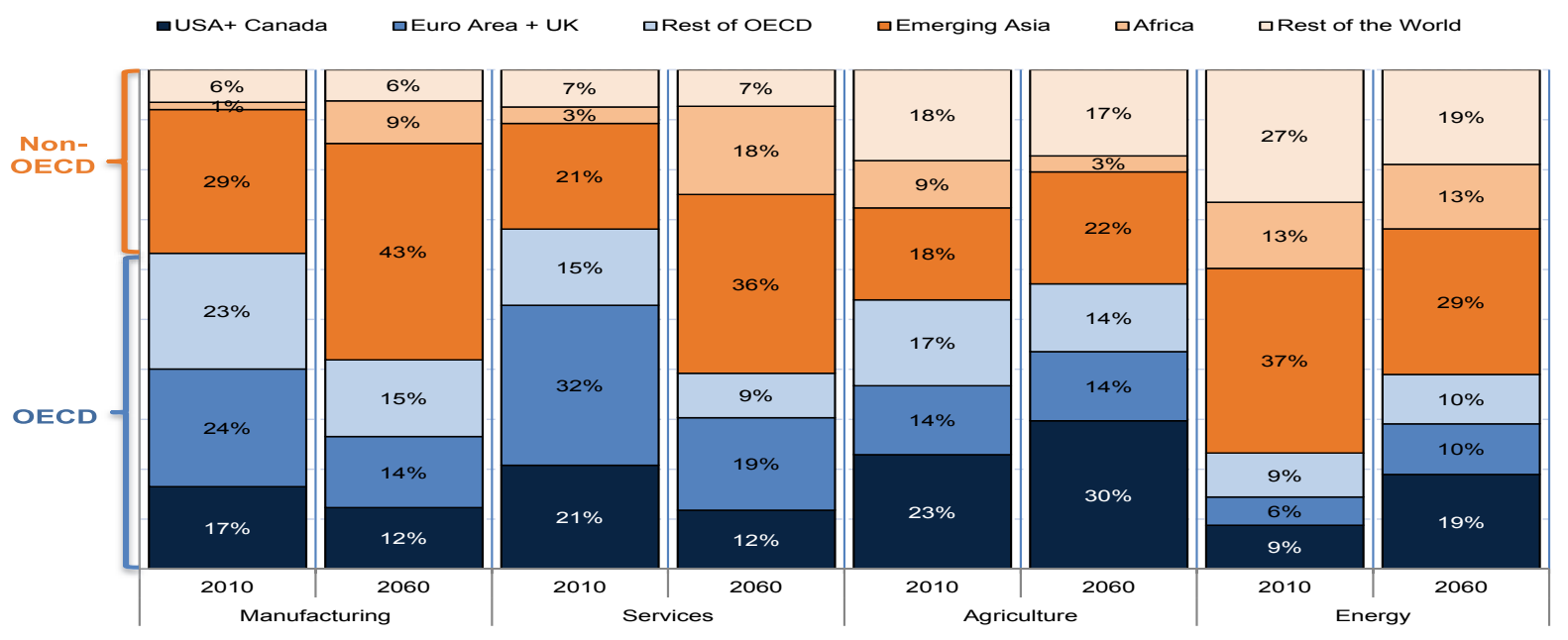

1. Manufacturing includes chemicals rubber and plastic, electronics, food, iron and steel, metal products, other manufacturing, other metals, other minerals, paper and wood, textiles, transport equipment. Service includes business service, transport service, wholesale and retail, public administration and other services. Agriculture includes livestock, rice and crops, other agriculture and other mining. Energy includes coal, crude oil, electricity, gas and refined oil.

\section{The industrial structure in emerging economies gradually becomes similar to that of the OECD}

53. In parallel with the changing trade patterns, the industrial structure (measured as value-added shares of specific sectors in total value-added) will evolve differently across countries and regions depending on changing patterns of domestic and international demand, differences in the accumulation of production factors across countries, the allocation of factors across sectors within countries and countries' international competitiveness. One general trend that stands out in the baseline projection is that most significant changes will occur in emerging economies, whereas the industrial structure will remain relatively stable in OECD countries over the next half century (Figure 9). This largely reflects the development process in lower-income countries with income and living standards catching-up towards levels of higher-income OECD countries, which results in changing domestic demand and consumption structure. Projections also show that trade costs remain large enough in certain industries to prevent a full shift of industrial activities to emerging economies away from OECD.

54. The industrial structure in fast-growing emerging countries will become more similar to the one in OECD economies. In emerging countries, past trends are expected to continue over the projection period and the industry mix will continue shifting towards services away from manufacturing, typically lowskilled (e.g. textile, food production etc.). China and India are projected to experience marked increases in the contribution of financial and business services, wholesale and retail and transport services to value added as domestic demand for these services increases with income and shift in comparative advantage (Figure 9). This increased similarity among OECD and emerging countries implies that intra-industry trade should account for a larger share of trade over the next half century, contrasting with the recent decline associated with the large contribution of highly specialized emerging economies to world exports.

55. Despite the general reorientation towards services, manufacturing industries are still expected to remain important in emerging economies. For instance, in China, Indonesia and other Asian countries the contribution of the auto industry to value-added will increase over the next 50 years. Likewise, electronics is projected to account for an increasing share of GDP in China, reflecting strong competitiveness in this sector. 
Figure 9. Industrial structure is set to change in emerging economies

Value-added shares of key industries by country, 2010 and 2060
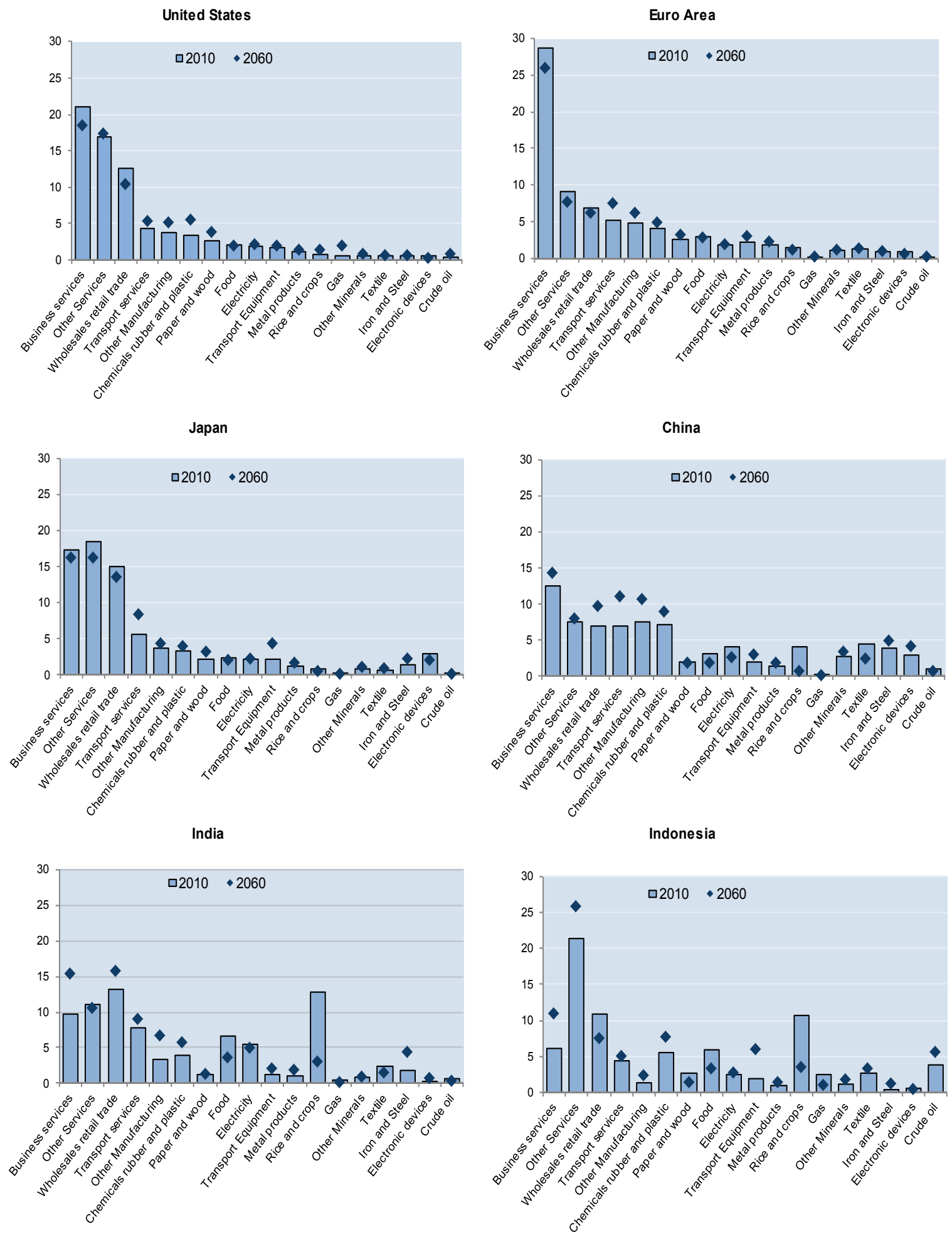


\section{Income convergence will influence wage inequality among and within countries}

56. Over the next 50 years income gaps among countries will narrow. Rapid GDP growth in emerging economies is matched by a tendency of GDP per capita to converge across countries. Between now and 2060, GDP per capita (measured in 2005 PPPs) in India, Philippines and some African countries will increase by more than 7 times, while the increase is around 5 times in Indonesia and China. Over the same period, living standards will roughly double in the highest-income OECD countries. This will lead to a richer and more equal distribution of world income among countries, which will push in the direction of falling absolute poverty.

57. Furthermore, across countries the relative wage of skilled to unskilled labour will change over the next half century, with implications for trade patterns. The distribution of wages across differently skilled workers within countries depends on the supply and demand for skills, the extent of skill-biased technological change, the composition of consumption demand and institutional settings in labour markets and educational systems. The projected framework can only account for the influences of the relative supply of different skills and demand effects due to changing income levels and specialisation patterns, but not the effect of skill-biased technical change and institutional settings. Over the next half century educational attainment will continue to improve, increasing the supply of skilled labour. This leads to downward pressure on the skill premium in the model framework. However, as shown in Braconier et al. (2014) continued skill-biased technological progress, with rapidly rising demand for higher skills, is likely to outpace the increase in the supply of skills, leading to increased wage inequality over the next 50 years.

\subsection{Trade liberalisation can increase global trade and growth}

58. This section gauges the impact of two stylised trade liberalisation scenarios on global trade, GDP, industrial structure and wage inequality over the next 50 years, compared with the baseline long-run scenario described above. As described in Section 3.2, one scenario considers strengthened regional integration among a set of current OECD economies (e.g. the United States, Canada, Mexico, the European Union, Switzerland, Australia, New Zealand, Japan and Korea), the other scenario considers trade liberalisation on a global basis.

\section{Though gravity factors are key drivers of trade over the long-run, trade policies still matter}

59. As previously highlighted in Fontagné and Fouré (2013) over the next decades changes in GDP will be the main driver of world trade, while changes in trade policies are unlikely to lead to changes of comparable magnitude (Figure 10). For instance, world goods exports are projected to increases by some $3.5 \%$ annually over the next 50 years due to changes in GDP, demography and other gravity factors, while regional trade and global multilateral liberalisation would add around 0.1 and 0.3 percentage points to annual OECD export growth, respectively. Thus, the projections suggest that OECD countries would not be able to keep their current position in world trade simply by moving towards deeper regional integration. 
Figure 10. Growth in GDP, exports of goods and services, 2012-2060

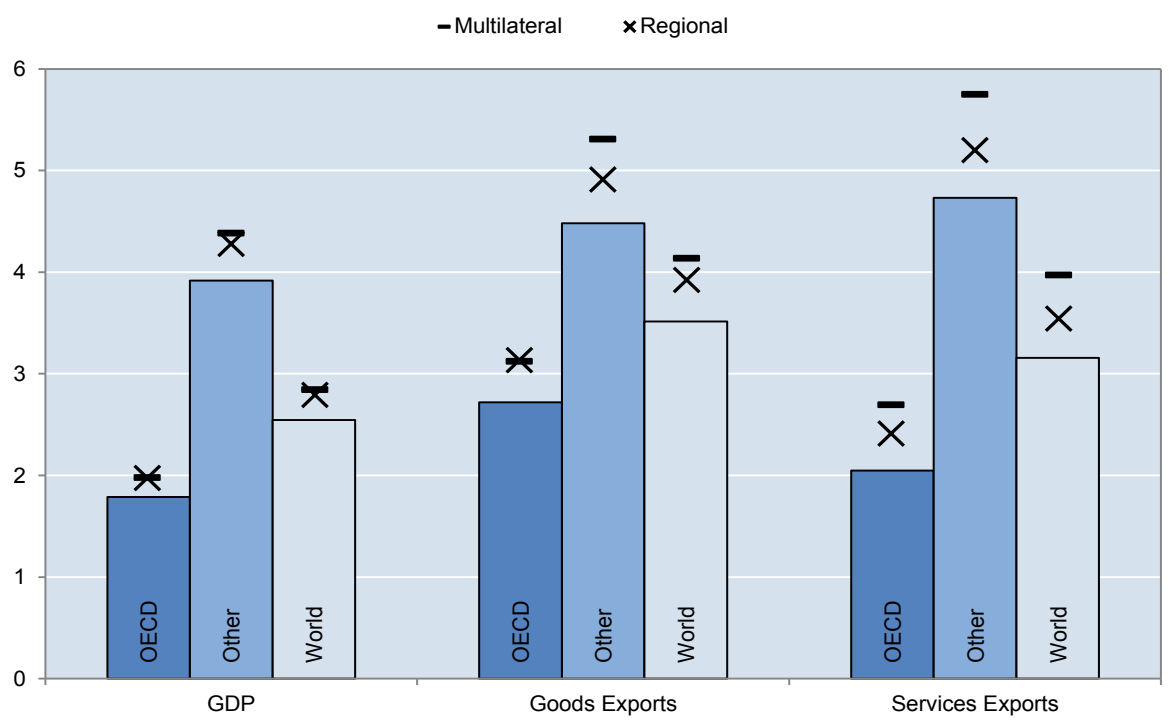

Unevenly distributed increases in trade from trade liberalisation

60. Projecting the alternative scenarios reveals mostly positive trade impacts across the globe but illustrates the different outcomes of regional versus multilateral approaches to trade liberalisation. World trade (exports) in the regional and partial multilateral liberalisation is $4 \%$ and $15 \%$ higher in 2060 , respectively, but the gains are distributed unevenly across countries or regions in the two scenarios (Figure 11). While the effect of trade liberalisation in FTA members (mostly OECD economies) is to raise trade by around $7-8 \%$ in both scenarios, non-FTA members (mostly non-OECD countries) only enjoy sizeable increases in trade in the multilateral scenario. For these economies the increase in trade is only about $1 \%$ in the regional liberalisation scenario despite the bilateral agreements they conclude with members of the large FTA area (NAFTA, the European Union, Australia, New-Zealand, Japan and Korea). By contrast, multilateral liberalisation could raise their trade by $15 \%$ to $30 \%$. An explanation for this is that non-tariff measures (transaction costs in goods and NTM in services) remain stable in the regional scenario, counteracting the reduction in tariffs. Nonetheless, as in the baseline, in both scenarios the bulk of all trade still occurs among non-OECD (non-FTA) countries or regions at the end of the projection period. 
Figure 11. Unevenly distributed increases in trade in liberalisation scenarios, 2060

$\%$ increase in gross exports as compared with the baseline by $2060, \%$

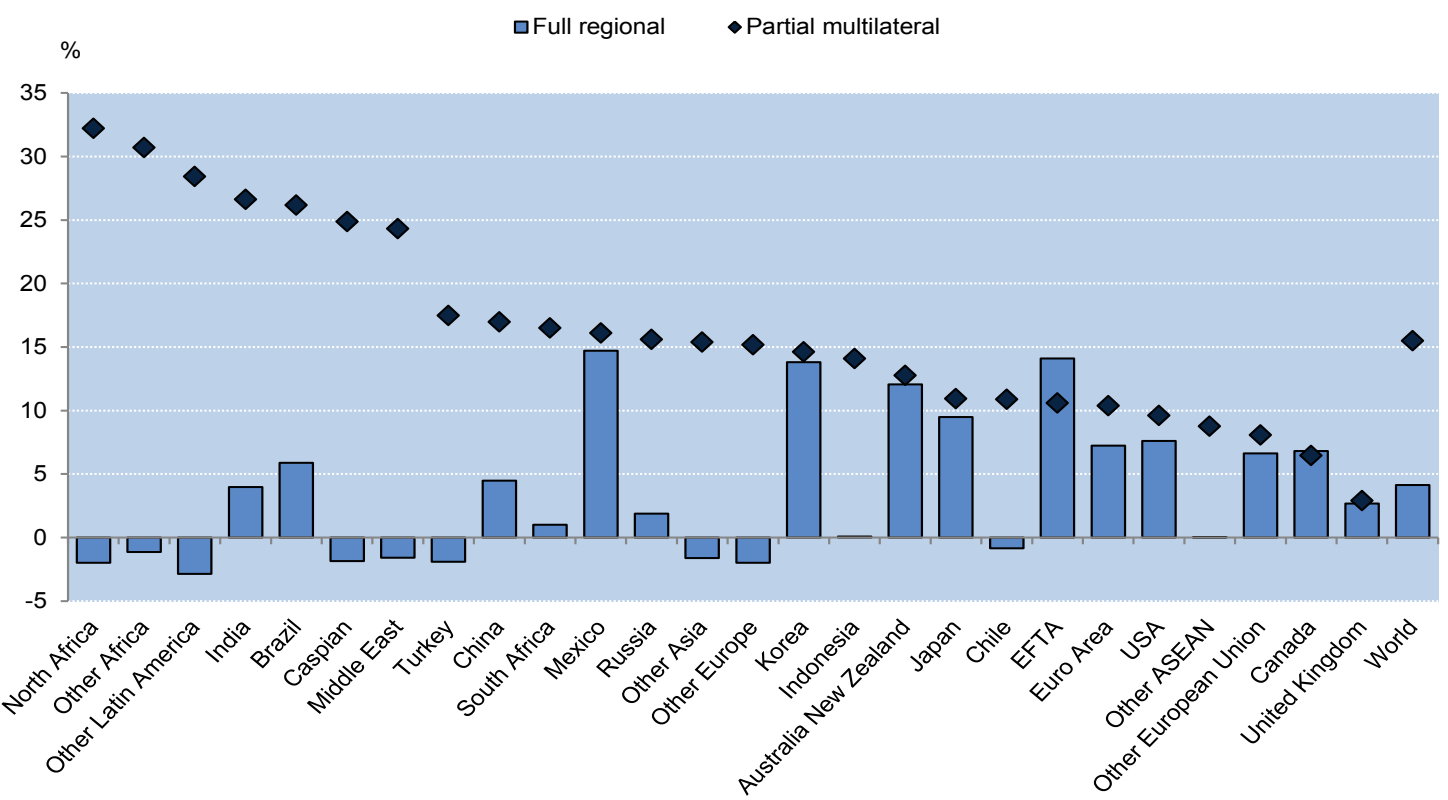

61. This asymmetry in the impact of liberalisation across OECD and non-OECD countries in the two scenarios can be explained by a reorientation of trade and by large trade diversion effects. In the regional liberalisation scenario, a share of potential trade will shift towards members of the FTA (OECD countries) away from non-members (non-OECD countries) (Figure 12). Part of this expansion of trade is replacing former trade of non-members with trade from regional members, as a result of the shift in relative market access conditions. As a result of this trade diversion some non-FTA countries will experience trade losses, particularly those in regions that do not sign a bilateral agreement with the FTA in 2030 (e.g. Africa, Latin America, the Middle East etc.). By contrast, in the partial multilateral scenario trade is instead reoriented away from OECD countries towards the non-OECD area, reflecting comparatively larger reductions in tariffs than in OECD countries (i.e. given that initial tariff levels in the baseline are higher in non-OECD than in OECD), as well as stronger underlying growth performance in this area. 
ECO/WKP(2014)38

Figure 12. Reorientation of trade towards FTA partners

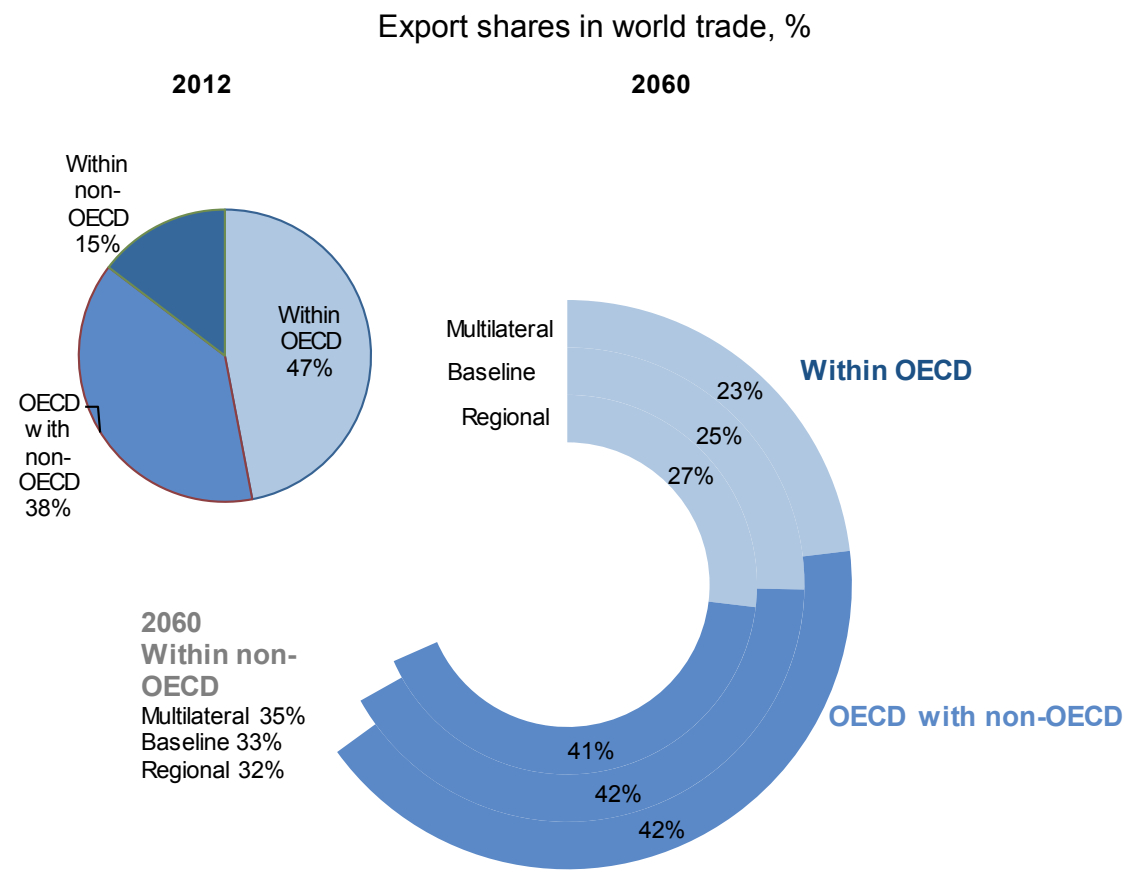

Trade liberalisation triggers moderate changes in trade specialisation and industrial structure

62. Trade liberalisation will increase international competition and induce a reallocation of resources across and within countries and industries. However, on the whole, the change over time in the trade specialisation and, in turn, broad industrial structure triggered by deeper trade liberalisation in the two scenarios tends to be moderate compared with that which already occurs in the baseline. One explanation is that the implemented trade scenarios do not introduce any significantly differentiation in trade liberalisation among different sectors. Accordingly, countries' trade specialisation pattern are not expected to change considerably as compared to the one observed in the baseline (Figure 13). Overall, this suggests that a larger share of the trade-induced reallocation of activities occurs within rather than between industries.

63. However, the change in trade specialisation in China that occurs in the multilateral scenario deserves a comment. Even though the education level in China will improve significantly over the next 50 years, multilateral trade liberalisation will slightly reinforce the Chinese specialisation in (low-skill intensive) textiles (from $11 \%$ to $12 \%$ ) at the expense of (higher-skill intensive) electronics (34 to $32 \%$ ). This is a consequence of the initial tariffs that China is facing in developed markets in these two sectors. The tariff on textiles is the highest tariff for manufactured goods that China is facing in Canada and the United States and the second highest in the Euro area, with these three regions being significant destinations for Chinese textile products. By contrast, Chinese electronic devices are facing initially the lowest tariff in the same three regions as well as being widely exported to them. As a result, halving these two tariffs imply a larger gain in revealed comparative advantage for textiles than for electronics, hence influencing the Chinese export specialisation. 
Figure 13. Export specialisation in manufactured products, 2060, volume

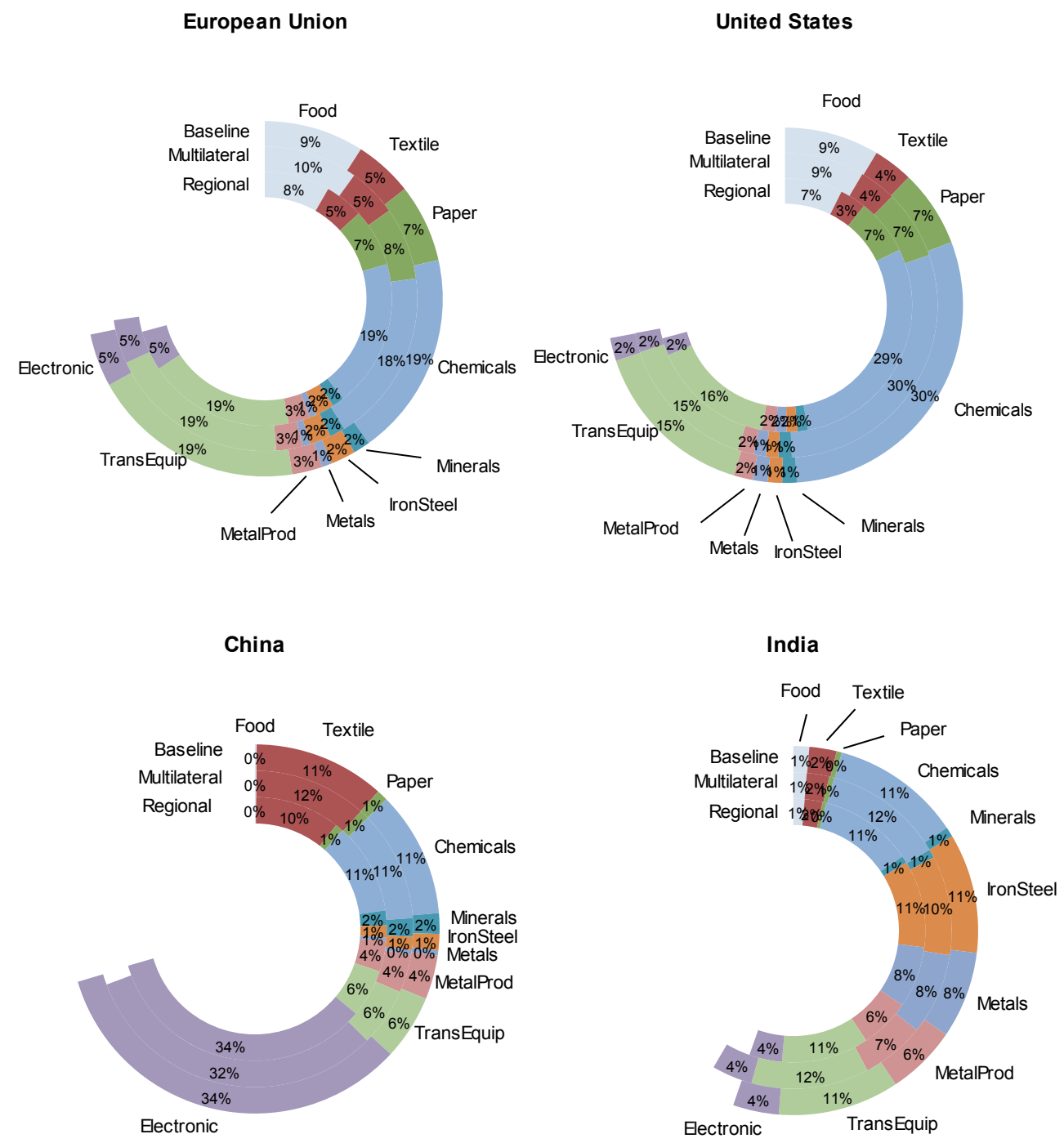

64. Turning to the change in the industrial structure induced by trade liberalisation some interesting patterns emerge. In both alternative scenarios, the industrial structure in the United States tends to shift over time towards agriculture (rice and crops) and food production away from other manufacturing (Figure 14). This reallocation comes about through increased international competitiveness in the export market reflecting increasing comparative advantage of the United States in this sector due to the combination of abundant arable land with the removal of high levels of agricultural support in some countries in the multilateral scenario. By contrast, the removal of agricultural support in the European Union (in the multilateral scenario) tends to reorient activities in the Euro area away from agriculture (rice and crops) towards manufacturing (e.g. the auto industry, transport services, textiles, food production). Similarly in Japan, in both scenarios, the activity moves away from agriculture and food production towards manufacturing, particularly transport equipment.

65. Among emerging economies, the change in industrial structure over the next half century is much more pronounced with partial multilateral liberalisation than with regional liberalisation, consistent with better market access and larger trade gains in the multilateral scenario. One common pattern is a shift towards manufacturing away from agriculture and food production. For instance, in India and Indonesia, 
by 2060 the value-added in the electronics sector would increase by more than $8 \%$ in the multilateral scenario, compared with baseline. Furthermore, multilateral liberalisation would increase the value-added of the auto industry by around $12 \%$ in India compared with baseline, reflecting a stronger impact of India's competitiveness in labour-intensive low and medium-skilled manufacturing. Interestingly, even though China's export specialisation in electronics is reduced in the multilateral scenario as compared with the baseline, the value added share of electronics in total value added increases by 2060 . This likely reflects a higher domestic demand for electronics, whose production relies less on foreign intermediate inputs. 
Figure 14. Reallocation of industrial activities, 2060

$\%$ increase in value added of industries as compared with the baseline in 2060

United States
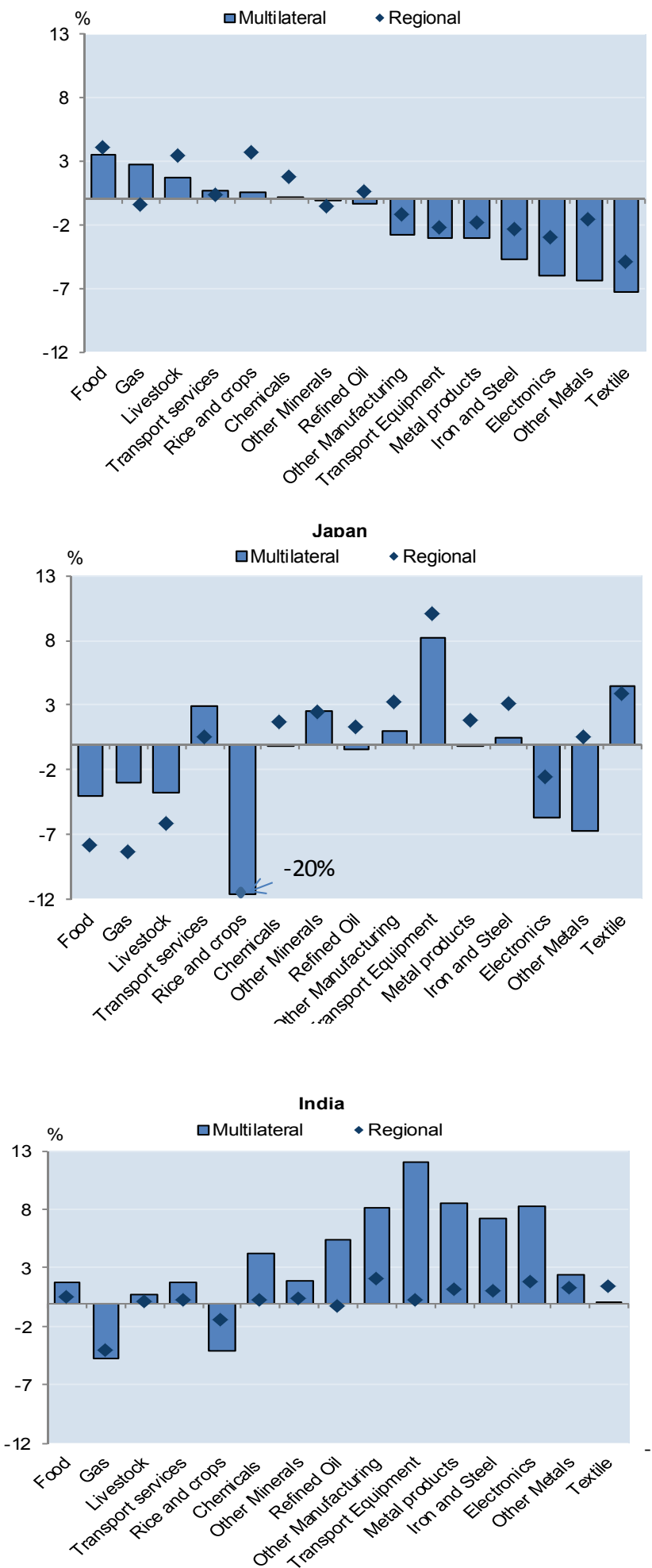

Euro Area
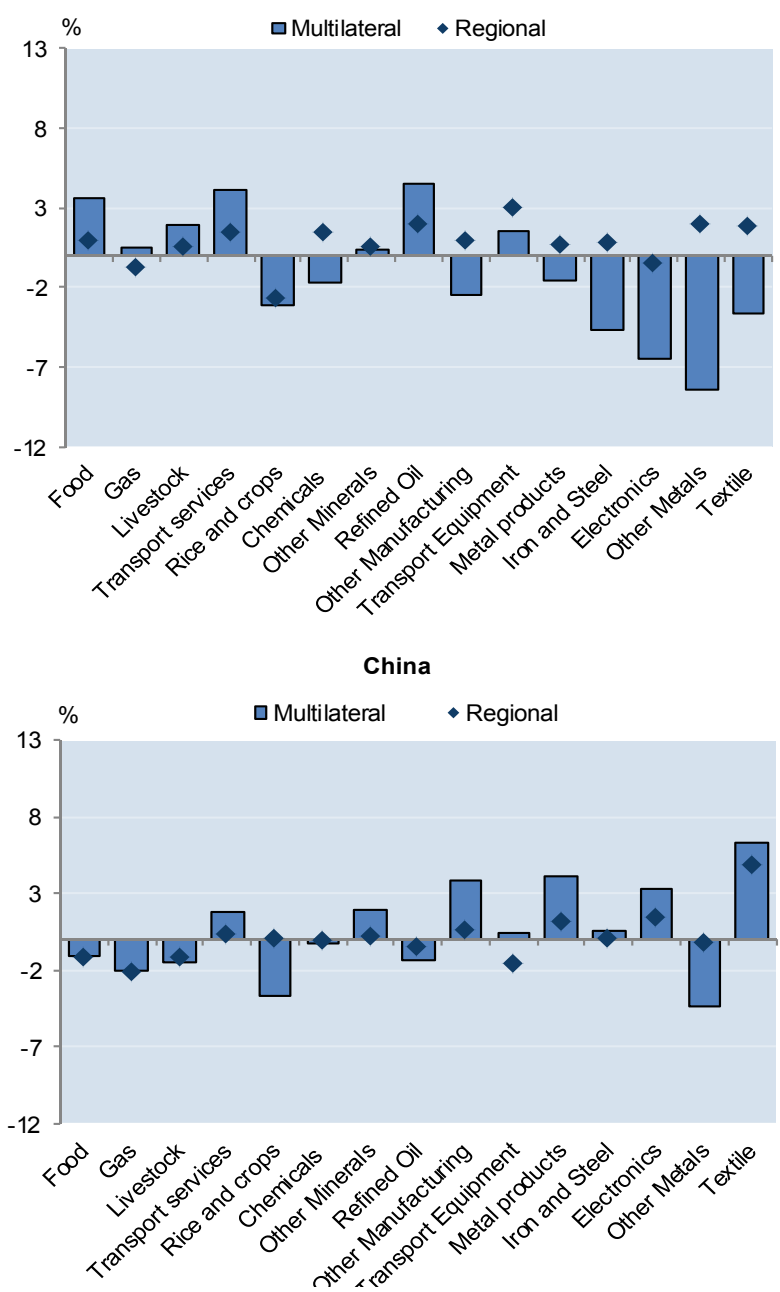

Indonesia

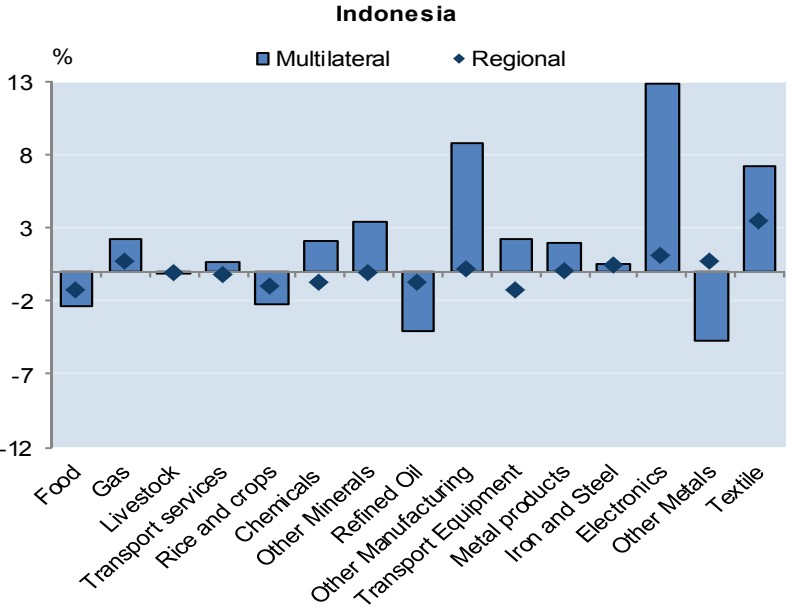




\section{Trade liberalisation has a positive impact on real GDP, more so if liberalisation is multilateral}

66. In parallel with the increased trade integration and associated reallocation of resources across sectors to comparatively more efficient ones, long-term real GDP will increase relative to baseline. World GDP in the regional and partial multilateral liberalisation scenarios is $0.6 \%$ and $2.8 \%$ higher in 2060 , respectively. But again, the gains in long-term GDP are unevenly distributed across the globe in the two scenarios. While the change in real GDP in most OECD countries is similar in the two scenarios, the gains are always greater for non-FTA members (mostly non-OECD countries) in the multilateral scenario. Multilateral liberalisation could raise long-term real GDP in India and other Asian regions by more than 4\% by 2060 (relative to baseline) (Figure 15).

67. The gains in terms of GDP illustrated here may appear modest compared with large changes observed as a result of growth fundamentals (e.g. demography, education, technical progress etc.). However, it should be kept in mind that, while the MIRAGE-e projections capture only allocative gains, a better trade environment and level playing field are pre-conditions to reap the growth benefits of the mentioned fundamentals. Feedback effects of increased trade openness on growth in terms of acceleration of productivity catch-up (due to knowledge spillovers and diffusion of technologies) are not taken into account in the multilateral liberalisation scenario modelled with MIRAGe-e. A separate exercise conduced with the OECD model suggests that global GDP would gain an additional $1.2 \%$ in 2060 , due to these indirect growth effects of trade liberalisation.

Figure 15. Trade liberalisation increases GDP, 2060

$\%$ increase in real GDP of trade liberalisation as compared with the baseline by 2060

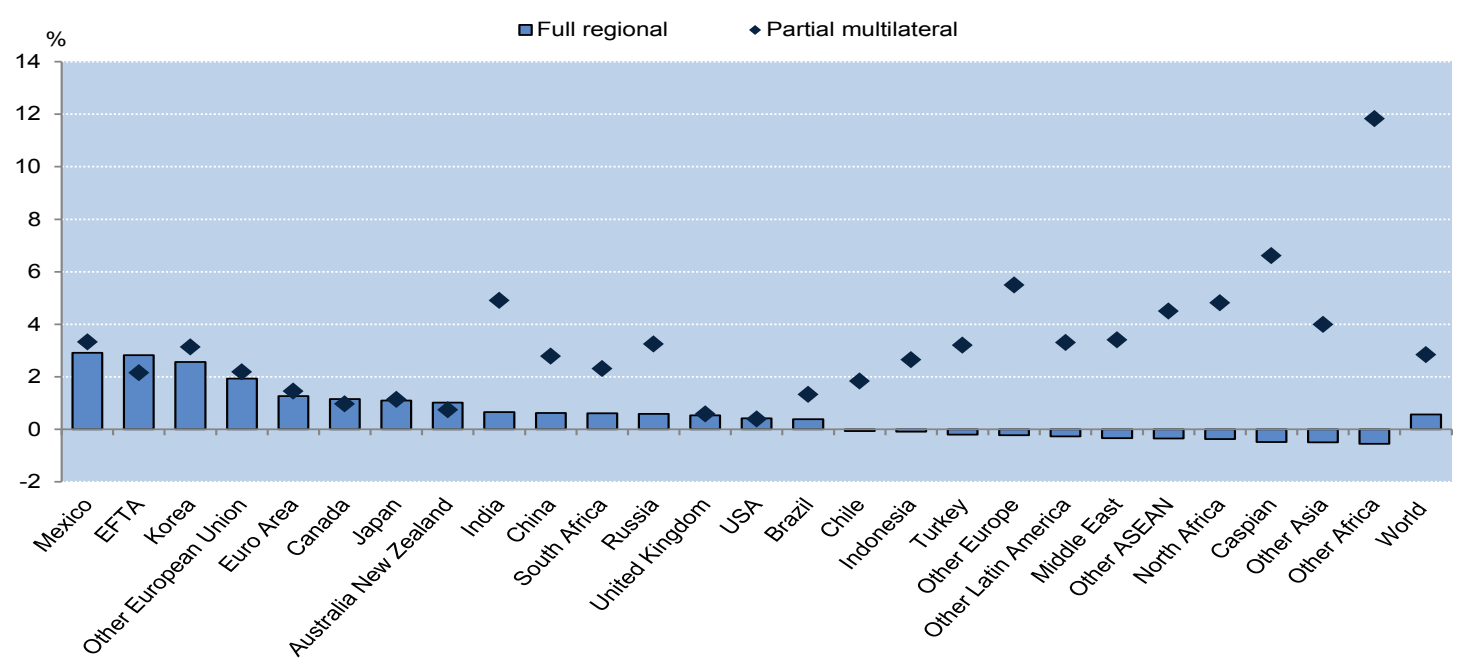

\section{Trade liberalisation tend to increase wage gaps between skilled and unskilled labour}

68. Relative wages will be affected by trade liberalisation since the demand for different types of skills changes with specialization. Any excess demand or supply of skilled and unskilled labour would be absorbed in relative factor prices Mirage-e projections. Table 5 presents the change in the differential between growth in skilled and unskilled wages for the two trade liberalisation scenarios. A positive number means that skilled wages have increased faster than unskilled wages, thus within-country wage inequalities (the skill premium) increase. Overall, there is a tendency for the wage gap between skilled and unskilled workers to widen in both advanced and emerging economies in the trade liberalisation scenarios relative to baseline. All categories of labour income (skilled and unskilled) increase in most developing and 
developed economies as a result of multilateral liberalisation, expanding relative demand for skilledintensive goods and services worldwide. This shift in consumption patterns increases the relative demand for skills at the global level.

69. In most cases, upwards pressures on skill premia are stronger in the multilateral liberalisation scenario than in the regional one, reflecting greater reallocation of resources across industries and countries towards higher-skilled activities. ${ }^{8}$ Generally, however, these additive pressures originating from trade liberalisation are moderate. Stronger pressures on skill premia are observed in the European countries and Japan, as demand shifts from low-skilled sectors towards higher-skilled ones, as well in some other advanced economies (e.g. the United Kingdom and EFTA countries). Pressures on wages of skilled workers are also significant in some developing economies such as Indonesia, India or South Africa due to the strong reorientation of production towards the relatively high-skilled electronic sector in combination with comparatively lower up-skilling than in some other emerging economies (e.g. China). Finally, a few developing economies display a decrease in both skilled and unskilled wages before signing bilateral agreements with FTA members in the regional liberalisation scenario (i.e. denoted by a star in Table 4). This is caused by the trade deviation associated with the implementation of the FTA.

Table 4. Skilled and unskilled wage developments 1

Percentage point change in the relative wage of skilled to unskilled as compared with baseline

\begin{tabular}{|c|c|c|c|c|c|}
\hline \multirow[b]{2}{*}{ Region } & \multicolumn{3}{|c|}{2030} & \multicolumn{2}{|c|}{2060} \\
\hline & Multilateral & Regional & & Multilateral & Regional \\
\hline Euro Area & 0.20 & 0.10 & & 0.79 & 0.41 \\
\hline United Kingdom & 0.23 & 0.12 & & 0.98 & 0.48 \\
\hline Other European Union & 0.24 & 0.11 & & 0.93 & 0.45 \\
\hline United States & 0.07 & 0.01 & & 0.24 & 0.03 \\
\hline Japan & 0.14 & 0.15 & & 0.55 & 0.63 \\
\hline Brazil & 0.02 & 0.02 & * & 0.21 & -0.00 \\
\hline Russian Federation & -0.55 & 0.04 & & -3.56 & 0.25 \\
\hline India & 0.15 & 0.02 & * & 0.75 & 0.10 \\
\hline China & 0.22 & -0.09 & * & 0.46 & -0.03 \\
\hline South Africa & 0.40 & 0.03 & & 1.74 & 0.01 \\
\hline Chile & -0.16 & 0.02 & * & -0.64 & 0.02 \\
\hline Indonesia & 0.32 & 0.00 & * & 1.62 & 0.17 \\
\hline Other ASEAN & 0.26 & 0.06 & * & 0.89 & 0.00 \\
\hline Turkey & 0.11 & 0.05 & & 0.26 & 0.26 \\
\hline Sub-Saharan Africa & 1.39 & 0.03 & & 5.20 & -0.04 \\
\hline
\end{tabular}

1. A positive number means that wage inequality between skilled and unskilled labour has risen, that is skilled wage increases more that unskilled wage or unskilled wage decreases more that skilled wage.

* Both skilled and unskilled wages are decreasing

8. It should be kept in mind that the model does not account for any feedback from skill premia to investment in education and the supply of skills, which could have implications for wage gaps. Also, any existence of shared rents between employers and employees in protected sectors prior to the trade liberalisation is not taken into account. 


\subsection{The speed of up-skilling in emerging economies influences GDP, trade and specialisation}

70. The speed of up-skilling has important implications for trade and specialisation across countries. To highlight this, this section compares the baseline GDP and trade projection with one in which China, India and Indonesia (CII economies) are assumed to approach the global frontier level of education much more slowly than in the baseline scenario as described in Section 3.3. Slower accumulation of human capital influences aggregate growth and by 2060 results in a decrease in real GDP by $7 \%$ for China, $12 \%$ for India and 9\% for Indonesia relative to baseline (Figure 16). This underlines the importance of skill accumulation for the development of these countries. There is also a more limited indirect impact in terms of GDP for other countries (less than $0.5 \%$ ) channelled through capital markets, because lower GDP means less savings and investment. ${ }^{9}$

Figure 16. Slower up-skilling reduces real GDP, 2005-2060 ${ }^{1}$

\section{Constant 2004 USD}

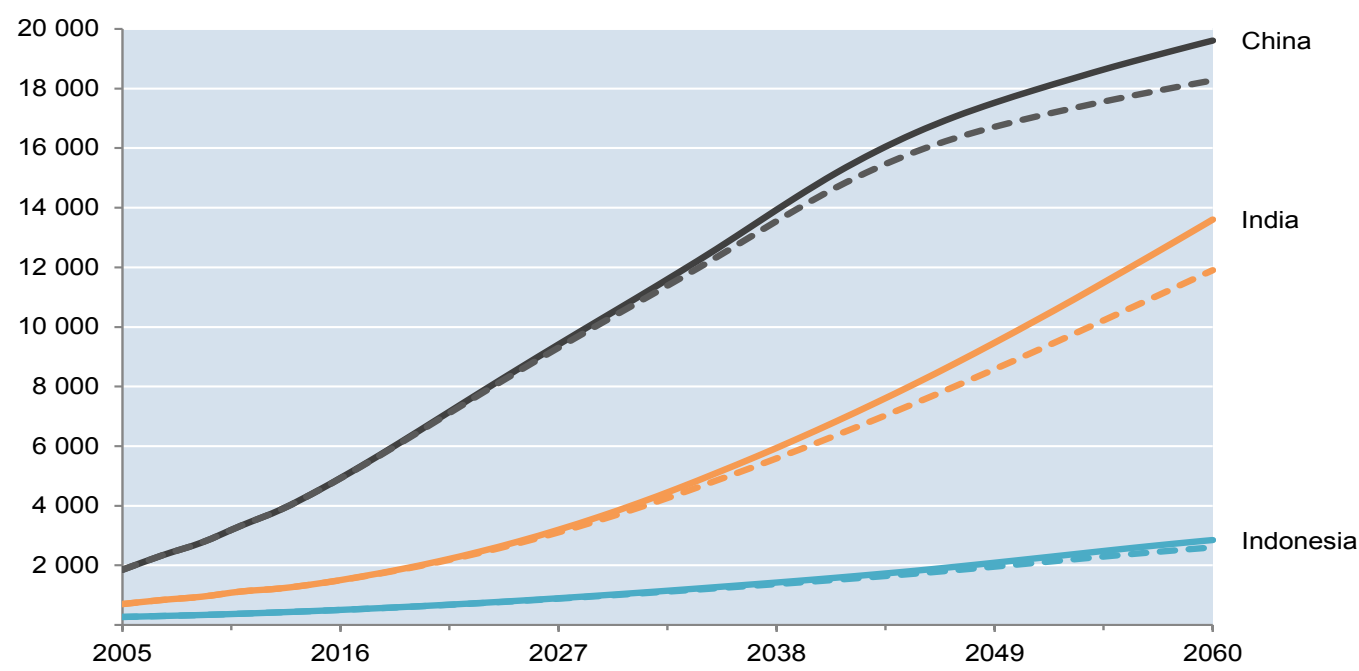

1. Plain line: baseline scenario; dashed line: lower up-skilling scenario

71. The reduction in aggregate growth due to slower accumulation of human capital in emerging economies affects trade across countries especially in CIIeconomies (Figure 17). Indeed, world trade is some $2 \%$ lower by 2060 in the slower upskilling scenario as compared with the baseline, mainly driven by decreases in CII economies exports (ranging between 6-11\%).

9. In the OECD model, this adjustment takes place through the price of capital, while in MaGE investment in the 105 countries is rescaled to match world savings. 
Figure 17. Effects on trade of lower upskilling in emerging economies, 2060

$\%$ change in gross exports as compared with the baseline by 2060

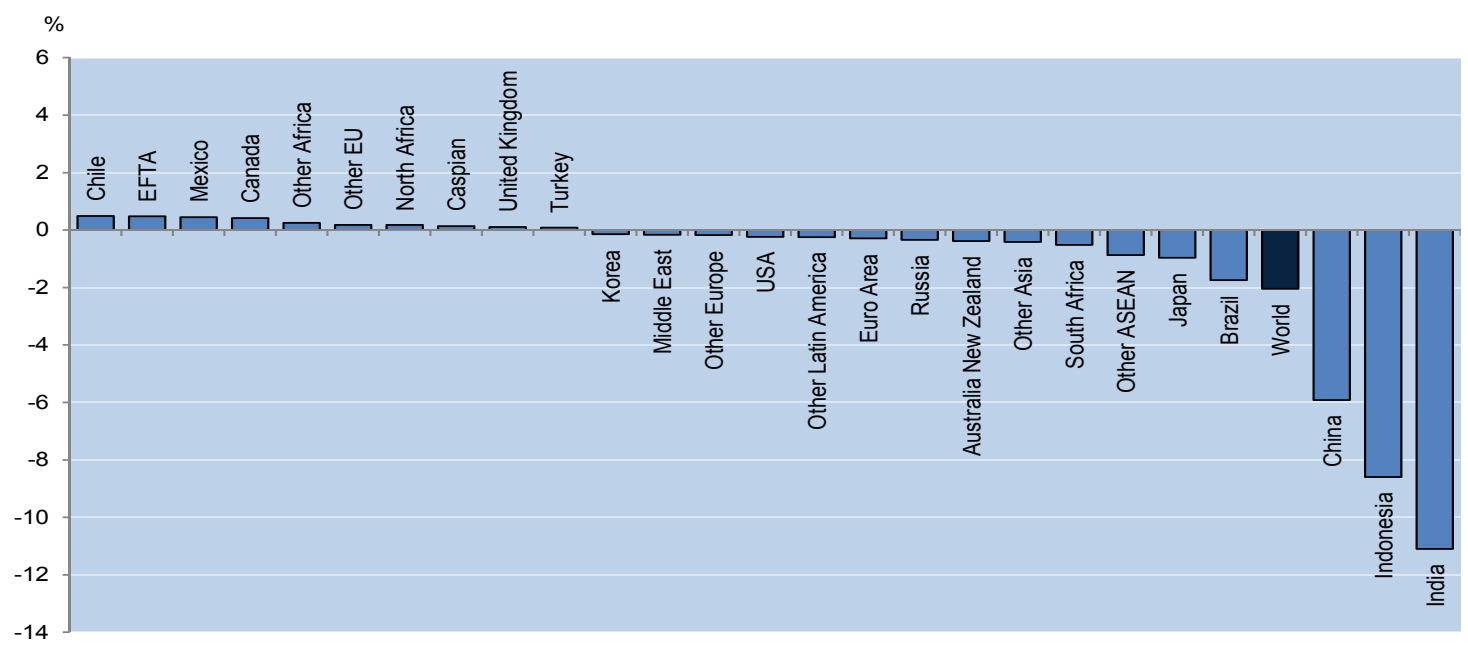

72. Slower upskilling in CIIeconomies implies that the reorientation of trade and production towards higher value-added manufacturing and services away from lower-skill activities occurs at a slower pace than in the baseline. For instance, in India and Indonesia by 2060 exports of business services and electronics would be $25 \%$ and $10 \%$ lower, respectively, whereas exports of agricultural goods (e.g. other agriculture, rice and crops, livestock) would be $5 \%$ and $15 \%$ higher, respectively, compared with the baseline (Figure 18). By contrast, slower upskilling in CIIeconomies implies that advanced economies (e.g. the United States, Japan and the Euro area) maintain their relative competitiveness in products that are intensive in human capital, such as electronics, business services and other manufacturing. 
Figure 18. Slower upskilling in China, India and Indonesia slows down their restructuring towards higher skilled activities

$\%$ change in volume of industrial exports as compared with the baseline in 2060

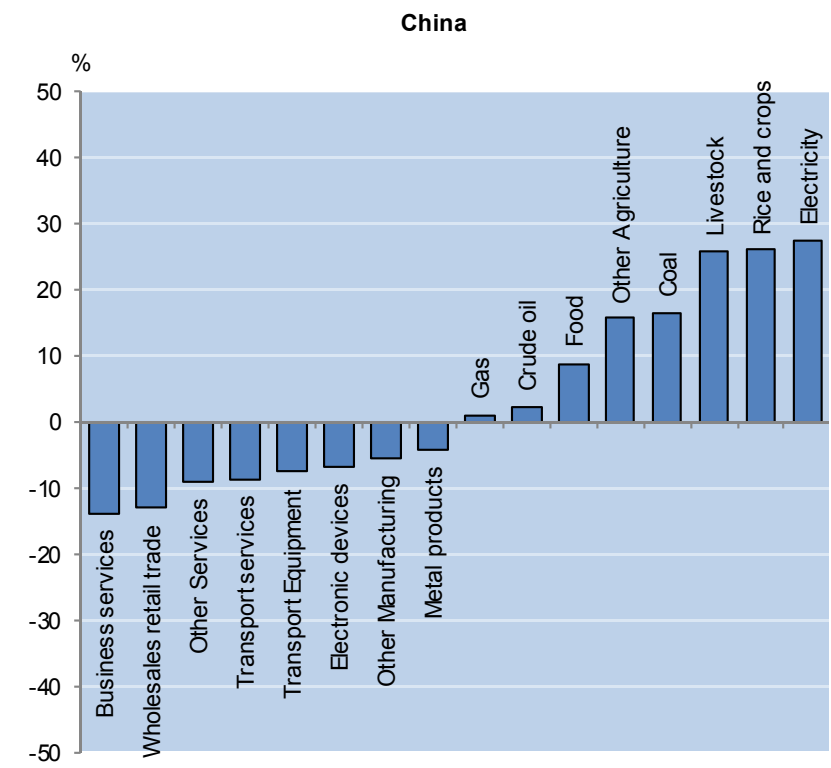

India

Indonesia
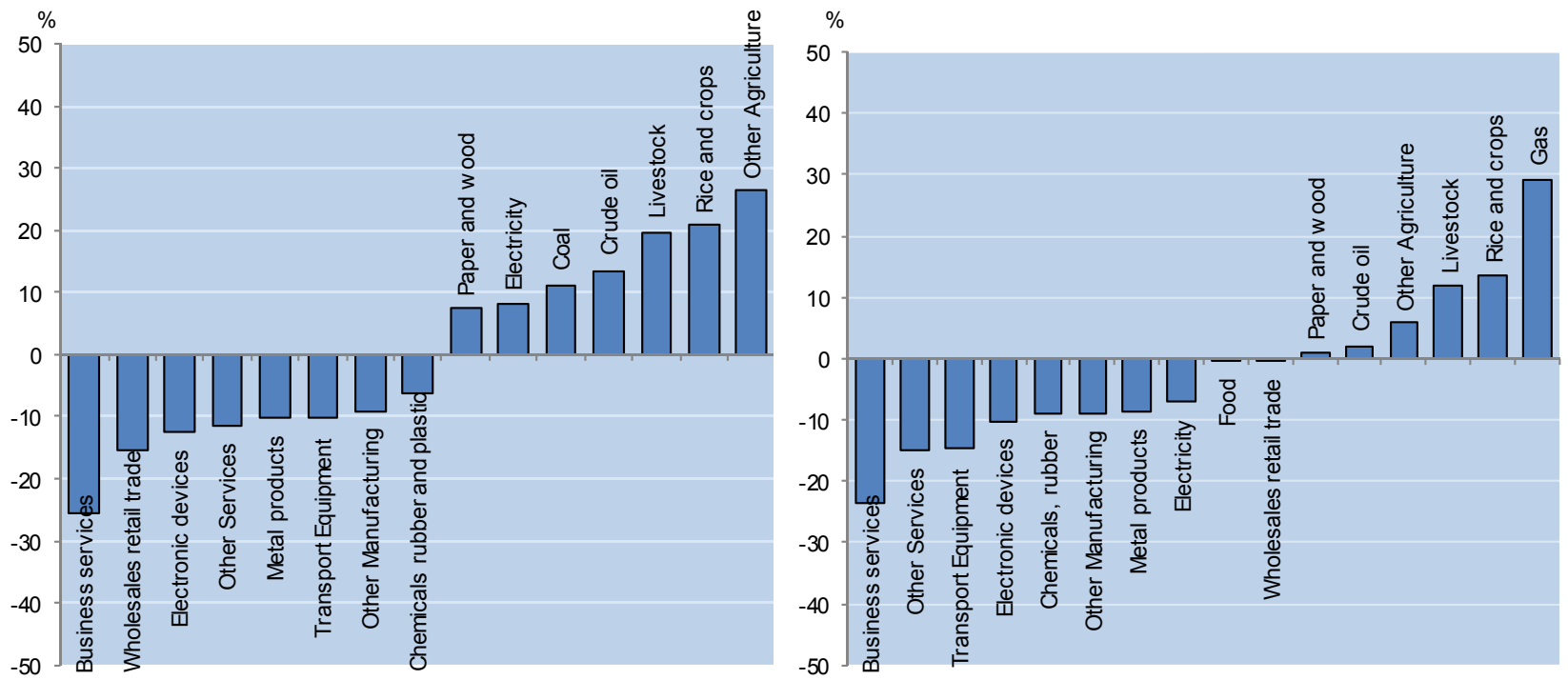

73. Such change in export specialisation is driven by developments in skilled and unskilled wages triggered by the slower upskilling in CII economies, which translate into variations in production prices. Slower upskilling in CII economies leads to a shortage of skilled workers relative to unskilled workers, which will increase the relative wage of skilled to unskilled labour as compared with the baseline. As shown in Figure 19, sector production price will vary according to skill intensity, with less skill-intensive sectors facing a decrease in their price and more skill-intensive ones an increase. Differences in the variation of production prices reflect cross-country differences in sectoral demand and factor endowments. In addition, changes in relative wages are not fully translated into changes in production prices due to substitution with other production factors. The induced change in production prices reshape a country's 
competitiveness influencing trading partners' demand for its goods (as well as for goods originating from all other countries).

Figure 19. Production prices: Selected sectors, 2060

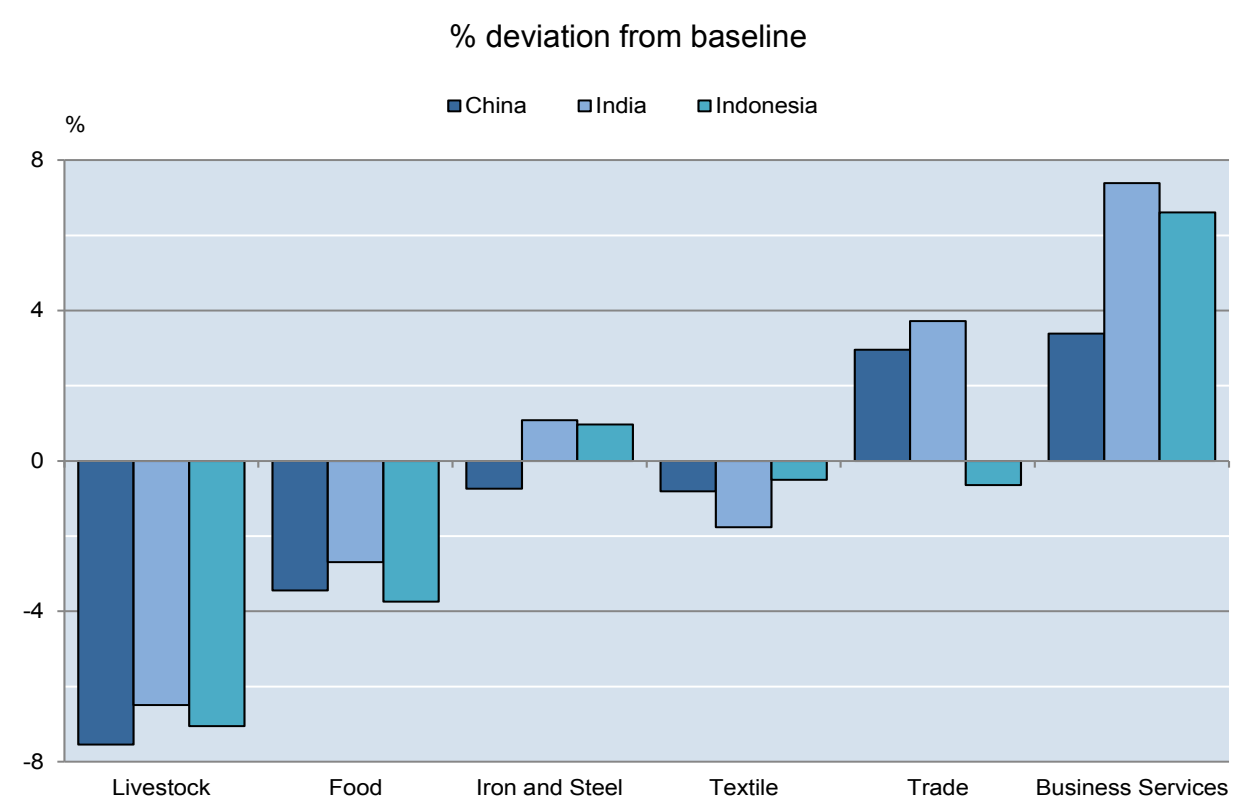

\section{Conclusion}

74. This paper draws global trade and specialisation scenarios up to 2060, taking into account international spillovers. Scenarios of trade and specialisation over the next 50 years are based on a framework that combines long-term macro projections for the world economy with a detailed sectoral general equilibrium model (Mirage-e). The combination of aggregate growth projections with the more detailed description of the behaviour of consumers and firms provided by the Mirage-e model allows highlighting how countries' specialisation is shaped by global trends (e.g. ageing, skill enhancement, capital investment, technology diffusion, etc.). It also highlights how structural and macro policies implemented in each country will affect future trade and specialisation patterns, taking into account interlinkages across countries.

75. The results of the exercise provide five main insights that can be useful to understand potential future developments of the world economy. First, the geographical center of trade will continue to shift towards emerging economies. Fast GDP growth in China, India and other Asian countries is associated with gains in trade shares over the next half century. Thus, the share of global trade within the present OECD will decline from $50 \%$ in 2012 to $25 \%$ by 2060 , while trade among non-OECD economies will account for approximately one-third of global trade.

76. Second, China, India and other Asian economies will continue to strengthen their role in manufacturing trade. For instance, by 2060 China and other Asian economies will account for the bulk of world exports in electronics. Significant shifts will also occur in services, with China and other emerging economies gaining large trade shares at the expense of the Euro Area, the United Kingdom and the United States.

77. Third, in parallel with shifts in trade patterns the industrial structure in emerging economies will gradually become similar to that of the present OECD, whereas it remains fairly unchanged in OECD economies. In emerging economies, past trends are expected to continue over the next 50 years and the 
industry mix will continue shifting towards services away from manufacturing, typically low-skilled (e.g. textile, food production, etc.), driven by income gains and changing consumption patterns.

78. Fourth, trade liberalisation will contribute to higher growth. In particular, gradually removing tariffs, regulatory barriers in services and agricultural support, as well as reducing transaction costs on goods (e.g. costs of handling at customs) could increase global trade and GDP over the next 50 years. Specific scenarios of regional or partial multilateral liberalisation among a core group of OECD countries could, respectively, raise trade by $4 \%$ and $15 \%$ and GDP by $0.6 \%$ and $2.8 \%$ by 2060 relative to the status quo. However, the gains would be distributed unevenly across countries. Regional liberalisation would bring greater gains to members of the free-trade agreement, notably OECD countries, rather than to nonmembers, due to trade diversion.

79. Finally, investment in education is crucial for trade and high-skill specialisation patterns over the coming decades. In fact, slower educational upgrading in key emerging economies (i.e. China, India and Indonesia) than expected in the baseline scenario could reduce world exports by $2 \%$ by 2060 , with decreases ranging between 6-11\% in China, India and Indonesia. Lower up-skilling in emerging economies would also slowdown the restructuring towards higher value-added activities in these emerging economies. 


\section{BIBLIOGRAPHY}

Armington, P. S. (1969), "A Theory of Demand for Products Distinguished by Place of Production", International Monetary Fund Staff Papers 16(1), 159-178.

Bouët, A., Y. Decreux, L. Fontagné, S. Jean and D. Laborde (2008), "Assessing Applied Protection Across the World", Review of International Economics, 16(5): 850-863.

Braconier, H, Nicoletti, G. and B. Westmore (2014), "Policy Challenges for the Next 50 years", OECD Economics Department Policy Papers, No. 9, OECD Publishing, Paris.

Decreux, Y. and H. Valin (2007), "MIRAGE, Updated Version of the Model for Trade Policy Analysis Focus on Agriculture and Dynamics", CEPII Working Paper No. 2007-15.

Fontagné, L. and J. Fouré (2013), “Opening a Pandora's Box: Modelling World Trade Patterns at the 2035 Horizon”, CEPII Working paper No 2013-22,

Fontagné, L., J. Fouré and M. P. Ramos (2013), "MIRAGE-e: A General Equilibrium Long-Term Path of the Word Economy", CEPII Working Paper No 2013-39.

Fontagné, L., A. Guillin and C. Mitaritonna (2011), "Estimations of Tariff Equivalents for the Services Sectors", CEPII Working Paper No. 2011-24.

Fouré, J., A. Bénassy-Quéré and L. Fontagné (2012), "The Great Shift: Macroeconomic Projections for the World Economy at the 2050 Horizon”, CEPII Working Paper No. 2012-03.

Fouré, J., A. Bénassy-Quéré and L. Fontagné (2013), "Modelling the World Economy at the 2050 Horizon", Economics of Transition, 21(4): 617-654.

Gouel, C. and D. Laborde (2007), “Prospective Agriculture 2013, Rapport Final”, CIREM, CEPII, Paris.

Guimbard, H., S. Jean, M. Mimouni and X. Pichot (2012), "MAcMap-HS6 2007, an Exhaustive and Consistent Measure of Applied Protection in 2007”, International Economics 130, 99-121.

Hertel, T., D. Hummels, M. Ivanic and R. Keeney (2007), "How Confident can we be of CGE-Based Assessments of Free Trade Agreements?", Economic Modelling 24(4), 611-635.

Hummels, D. and G. Schaur (2012), "Time as a Trade Barrier”, NBER Working Paper No. 17758.

IEA (2012), “World Energy Outlook 2012”, International Energy Agency, OECD Publishing, Paris.

Johansson, Å., Y. Guillemette, F. Martin, D. Turner, G. Nicoletti, C. de la Maisonneuve, P. Bagnoli, G. Bousquet and F. Spinelli (2013), "Long-Term Growth Scenarios", OECD Economics Department Working Papers No.1000, OECD Publishing, Paris.

van der Mensbrugghe, D. (2005), "LINKAGE Technical Reference Document: Version 6.0”, World Bank, Washington, D.C.

Minor, P. and M. Tsigas (2008), "Impacts of Better Trade Facilitation in Developing Countries", 11th Annual Conference on Global Economic Analysis, Helsinki.

OECD (2013), OECD Economic Outlook No. 93, OECD Publishing, Paris.

Wolff, E. N. (1999), "The Productivity Paradox: Evidence from Indirect Indicators of Service Sector Productivity Growth", The Canadian Journal of Economics 32(2), 281-308. 


\section{APPENDIX 1: ADDITIONAL DATA}

Figure A.1. Trade shares in selected industries, 2010 and 2060 $\%$ of world exports
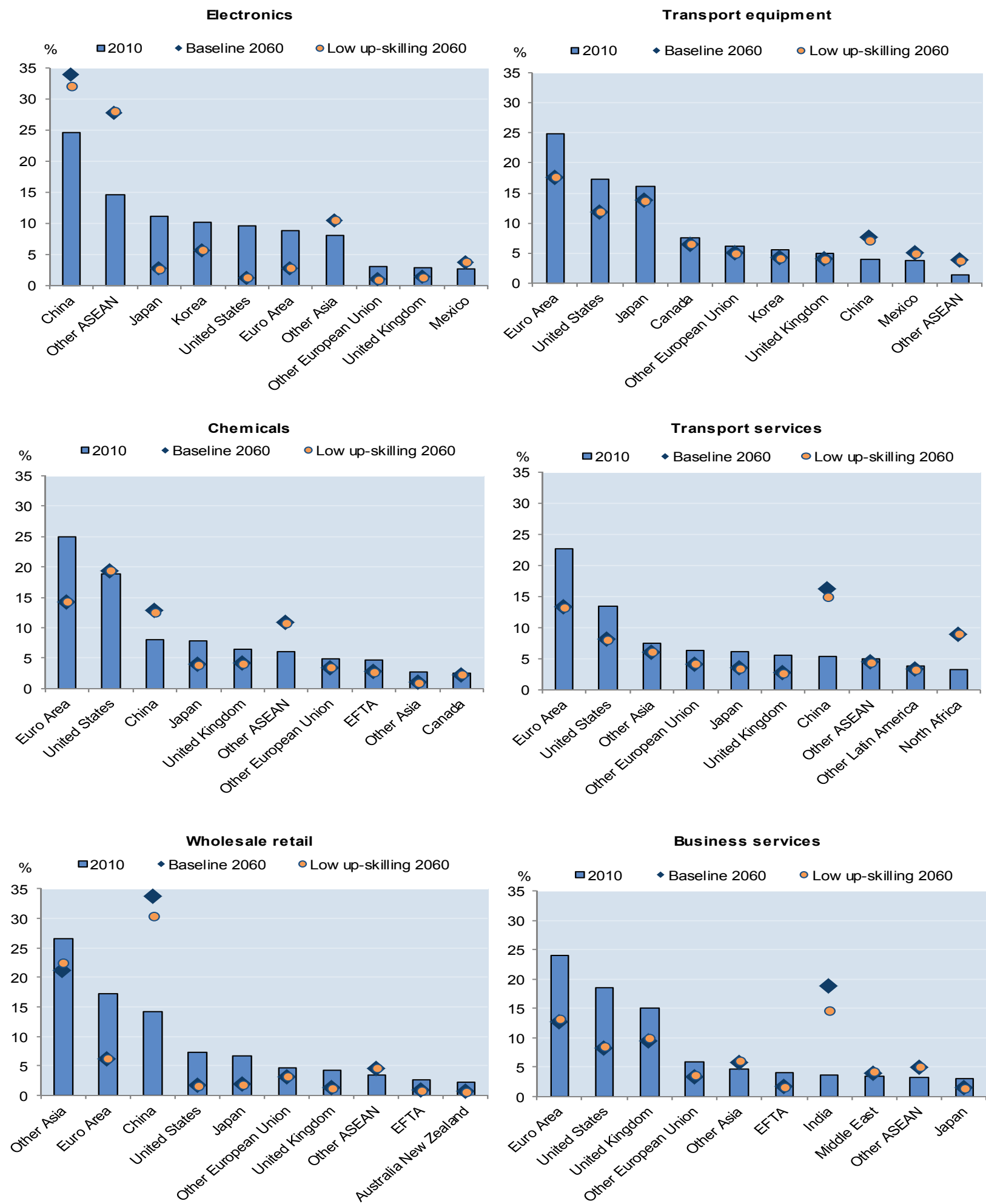
ECO/WKP(2014)38

\section{WORKING PAPERS}

The full series of Economics Department Working Papers can be consulted at www.oecd.org/eco/workingpapers

1141. The Demand for Skills 1995-2008: A global chain perspective

(July 2014) by Bart Los, Marcel P. Timmer and Gaaitzen J. De Vries

1140. International migration: The relationship with economic and policy factors in the home and destination country

(July 2014) by Ben Westmore

1139. Gross earning inequalities in OECD countries and major non-member economies: determinants and future scenarios

(July 2014) by Henrik Braconier and Jenifer Valenzuela Ruiz

1137. Managerial capital and business R\&D as enablers of productivity convergence

(September 2014) Dan Andrews and Ben Westmore

1136. Long-term patterns of trade and specialisation

(July 2014) by Asa Johansson and Eduardo Olaberria

1135. Consequences of climate change damages for economic growth - a dynamic quantitative assessment

(July 2014) by Rob Dellink, Elisa Lanzi, Jean Chateau, Francesco Bosello, Ramiro Parrado and Kelly de Bruin

1134. Comparing the robustness of PAYG pension schemes

(July 2014) by Falilou Fall

1133. Overcoming vulnerabilities of pension systems

(July 2014) by Falilou Fall and Debbie Bloch

1132. Overcoming vulnerabilities of health care systems

(July 2014) by Mauro Pisu

1131. Overcoming vulnerability of unemployment insurance schemes

(July 2014) by Jon Pareliussen

1130. Vulnerability of social institutions: Lessons from the recent crisis and historical episodes

(July 2014) by Falilou Fall, Mauro Pisu, Jon Pareliussen and Debbie Bloch

1129. An update of the OECD international trade equations

(June 2014) by Myriam Morin and Cyrille Schwellnus

1128. What explains the volume and composition of trade? Industrial evidence from a panel of countries

(June 2014) by Asa Johansson, Przemyslaw Kowalski, Eduardo Olaberria and Dario Pellegrino

1127. Do resources flow to patenting firms: cross-country evidence from firm level data (June 2014) by Dan Andrews, Chiara Criscuolo and Carlo Menon 
1126. Macroprudential policy tools in Norway: Strengthening financial system resilience (June 2014) by Yosuke Jin, Patrick Lenain and Paul O’Brien

1125. Strengthening competition in Poland

(June 2014) by Balász Égert and Antoine Goujard

1124. Making the labour market work better in Poland (June 2014) by Hervé Boulhol

1123. Enhancing competition and the business environment in Hungary (June 2014) by Alvaro Pina

1122. Tackling labour mismatches and promoting mobility in Hungary (June 2014) by Stéphane Sorbe

1121. Local public finances and municipal reform in Finland (June 2014) by Christophe André and Clara Garcia

1120. The economic consequences of ageing: the case of Finland (June 2014) by Christine de la Maisonneuve, Christophe André, Clara Garcia and Vincent Koen

1119. Making the most of skills in Denmark

(June 2014) by Stéphanie Jamet and Vincent Koen

1118. Trade specialisation and policies to foster competition and innovation in Denmark (June 2014) by Müge Adalet McGowan

1117. Policies for making the Chilean labour market more inclusive (June 2014) by Aida Caldera Sanchez

1116. Spillover effects from exiting highly expansionary monetary policies

(May 2014) by Łukasz Rawdanowicz, Romain Bouis, Jérôme Brezillon, Ane Kathrine Christensen and Kei-Ichiro Inaba

1115. Economic policies and microeconomic stability: A literature review and some empirics (April 2014) by Paula Garda and Volker Ziemann

1114. How to improve Israel's health-care system (April 2014) by Philip Hemmings

1113. How to improve taxes and transfers in Israel (April 2014) by Philip Hemmings

1112. New evidence on the determinants of industrial specialisation (April 2014) by Åsa Johansson and Eduardo Olaberría 